Prepared in cooperation with the U.S. Army Corps of Engineers

\title{
Total Dissolved Gas and Water Temperature in the Lower Columbia River, Oregon and Washington, Water Year 2014
}

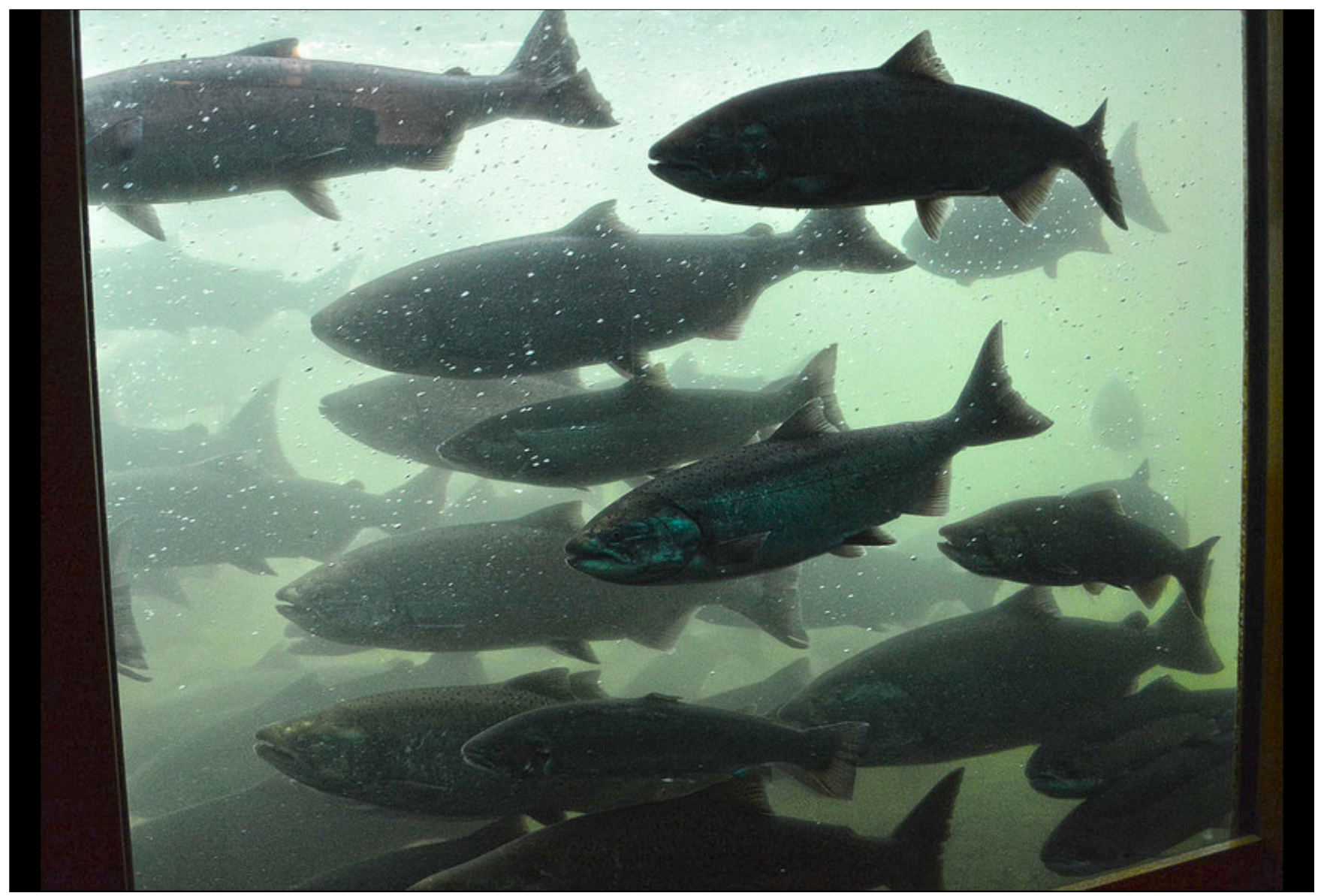

Open-File Report 2014-1237

U.S. Department of the Interior

U.S. Geological Survey 
Cover: Salmon swimming past the fish ladder viewing window at Bonneville Dam on the Columbia River on their way upriver to spawning grounds. The U.S. Geological Survey measures dissolved gas levels in the river to help the U.S. Army Corps of Engineers regulate spill from its dams on the lower Columbia River to minimize the production of excess dissolved gas downstream of the dams. Dissolved gas concentration greater than 110 percent saturation is harmful to fish migrating downstream through the spillways on their way to the ocean. (Photograph courtesy of the U.S. Army Corps of Engineers) 


\section{Total Dissolved Gas and Water Temperature in the Lower Columbia River, Oregon and Washington, Water Year 2014}

By Heather M. Bragg and Matthew W. Johnston

Prepared in cooperation with the U.S. Army Corps of Engineers

Open-File Report 2014-1237

U.S. Department of the Interior

U.S. Geological Survey 


\section{U.S. Department of the Interior \\ SALLY JEWELL, Secretary}

\section{U.S. Geological Survey \\ Suzette M. Kimball, Acting Director}

U.S. Geological Survey, Reston, Virginia: 2015

For more information on the USGS-the Federal source for science about the Earth,

its natural and living resources, natural hazards, and the environment-visit

http://www.usgs.gov or call 1-888-ASK-USGS

For an overview of USGS information products, including maps, imagery, and publications, visit http://www.usgs.gov/pubprod

To order this and other USGS information products, visit http://store.usgs.gov

Suggested citation:

Bragg, H.M., and Johnston, M.W., 2015, Total dissolved gas and water temperature in the lower Columbia River, Oregon and Washington, water year 2014: U.S. Geological Survey Open-File Report 2014-1237, 26 p., http://dx.doi.org/10.3133/ofr20141237.

ISSN 2331-1258 (online)

Any use of trade, firm, or product names is for descriptive purposes only and does not imply endorsement by the U.S. Government.

Although this information product, for the most part, is in the public domain, it also may contain copyrighted materials as noted in the text. Permission to reproduce copyrighted items must be secured from the copyright owner. 


\section{Contents}

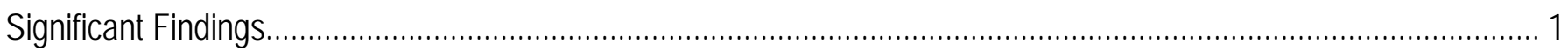

Introduction

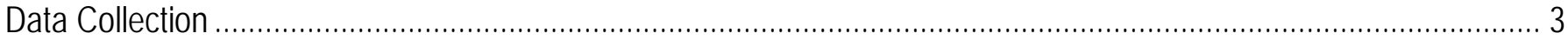

Data Completeness

Quality-Assurance Data

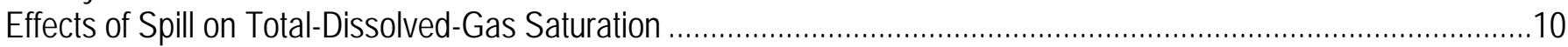

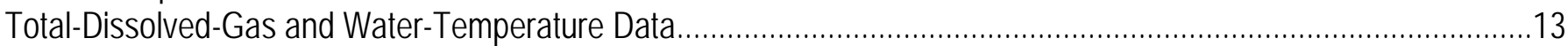

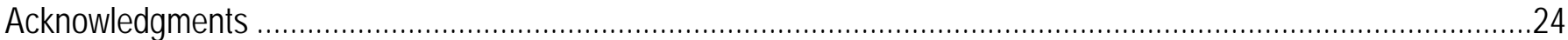

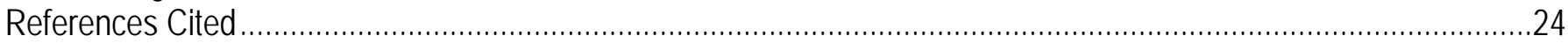

\section{Figures}

Figure 1. Location of U.S. Army Corp of Engineers dams and total-dissolved-gas monitoring stations, lower Columbia River, Oregon and Washington, water year 2014.

Figure 2. Boxplot showing accuracy of total-dissolved-gas sensors in the laboratory after 3 or 4 weeks of field deployment at eight monitoring stations in the lower Columbia River, Oregon and Washington, water year 2014 ........ 8

Figure 3. Boxplot showing difference between the secondary standard and the field barometers in the field after 3 or 4 weeks of deployment at eight stations in the lower Columbia River, Oregon and Washington, water year 2014 ...... 9

Figure 4. Boxplot showing difference between the secondary standard and the field temperature instruments in the field after 3 or 4 weeks of deployment at eight stations in the lower Columbia River, Oregon and Washington, water year 2014

Figure 5. Boxplot showing difference between the secondary standard and the field total-dissolved-gas instruments in the field after 3 or 4 weeks of deployment at eight stations in the lower Columbia River, Oregon and Washington, water year 2014.

Figure 6. Graph showing relation of total-dissolved-gas saturation downstream of John Day Dam and spill from John Day Dam, lower Columbia River, Oregon and Washington, April 1-August 31, 2014.

Figure 7. Graph showing relation of total-dissolved-gas saturation downstream of The Dalles Dam and spill from The Dalles Dam, lower Columbia River, Oregon and Washington, April 1-August 31, 2014.

Figure 8. Graph showing relation of total-dissolved-gas saturation downstream of Bonneville Dam at Cascade Island and spill from Bonneville Dam, lower Columbia River, Oregon and Washington, April 1-August 31, 2014.

Figure 9. Boxplot showing distributions of hourly total-dissolved-gas data, lower Columbia River, Oregon and Washington, April 1-August 31, 2014.

Figure 10. Graphs showing total-dissolved-gas saturation at John Day Dam navigation lock and spill from McNary Dam (76 river miles upstream of John Day Dam), lower Columbia River, Oregon and Washington, April 1-August 31, 2014.

Figure 11. Graphs showing total-dissolved-gas saturation at John Day Dam tailwater and spill from John Day Dam, lower Columbia River, Oregon and Washington, April 1-August 31, 2014.

Figure 12. Graphs showing total-dissolved-gas saturation at The Dalles Dam forebay and spill from John Day Dam, lower Columbia River, Oregon and Washington, April 1-August 31, 2014.

Figure 13. Graphs showing total-dissolved-gas saturation at The Dalles Dam tailwater and spill from The Dalles Dam, lower Columbia River, Oregon and Washington, April 1-August 31, 2014. 
Figure 14. Graphs showing total-dissolved-gas saturation at Bonneville Dam forebay and spill from The Dalles Dam, lower Columbia River, Oregon and Washington, April 1-August 31, 2014.

Figure 15. Graphs showing total-dissolved-gas saturation at Cascade Island and spill from Bonneville Dam, lower Columbia River, Oregon and Washington, April 1-August 31, 2014.

Figure 16. Graphs showing total-dissolved-gas saturation at Warrendale and spill from Bonneville Dam, lower Columbia River, Oregon and Washington, April 1-August 31, 2014.

Figure 17. Graphs showing total-dissolved-gas saturation at Camas and spill from Bonneville Dam, lower Columbia River, Oregon and Washington, April 1-August 31, 2014.

Figure 18. Graph showing hourly water temperature values upstream of John Day Dam and downstream of John Day Dam, lower Columbia River, Oregon and Washington, summer 2014.

Figure 19. Graph showing hourly water temperature values upstream and downstream of The Dalles Dam, lower Columbia River, Oregon and Washington, summer 2014

Figure 20. Graph showing hourly water temperature values upstream of Bonneville Dam and downstream of Bonneville Dam at Cascade Island, lower Columbia River, Oregon and Washington, summer 2014.

Figure 21. Graph showing hourly water temperature values upstream of Bonneville Dam and downstream of Bonneville Dam at Warrendale, lower Columbia River, Oregon and Washington, summer 2014.

Figure 22. Graph showing hourly water temperature values downstream of Bonneville Dam at Camas, lower Columbia River, Oregon and Washington, summer 2014

\section{Tables}

Table 1. Total-dissolved-gas monitoring stations, lower Columbia River, Oregon and Washington, water year 2014.4

Table 2. Completeness and quality of total-dissolved gas data, lower Columbia River, Oregon and Washington, water year 2014.

Table 3. Periods of missing real-time total-dissolved-gas data, lower Columbia River, Oregon and Washington, water year 2014 


\section{Conversion Factors}

\begin{tabular}{lll}
\hline \multicolumn{1}{c}{ Multiply } & \multicolumn{1}{c}{ By } & \multicolumn{1}{c}{ To obtain } \\
\hline cubic foot per second $\left(\mathrm{ft}^{3} / \mathrm{s}\right)$ & 0.02832 & cubic meter per second $\left(\mathrm{m}^{3} / \mathrm{s}\right)$ \\
mile $(\mathrm{mi})$ & 1.609 & kilometer $(\mathrm{km})$ \\
millimeter $(\mathrm{mm})$ & 0.03937 & inch (in.) \\
square mile $\left(\mathrm{mi}^{2}\right)$ & 2.590 & square kilometer $\left(\mathrm{km}^{2}\right)$ \\
\hline
\end{tabular}

Temperature in degrees Celsius $\left({ }^{\circ} \mathrm{C}\right)$ may be converted to degrees Fahrenheit $\left({ }^{\circ} \mathrm{F}\right)$ as ${ }^{\circ} \mathrm{F}=\left(1.8 \times{ }^{\circ} \mathrm{C}\right)+32$.

\section{Datum}

Horizontal coordinate information is referenced to the North American Datum of 1927 (NAD 27).

\section{Abbreviations}

$\begin{array}{ll}\text { BON } & \text { Bonneville forebay } \\ \text { CCIW } & \text { Cascade Island } \\ \text { CWMW } & \text { Camas } \\ \text { DCP } & \text { Data-collection platform } \\ \text { JDY } & \text { John Day navigation lock } \\ \text { JHAW } & \text { John Day tailwater } \\ \text { NIST } & \text { National Institute of Standards and Technology } \\ \text { RM } & \text { River mile } \\ \text { TDA } & \text { The Dalles forebay } \\ \text { TDDO } & \text { The Dalles tailwater } \\ \text { TDG } & \text { Total dissolved gas } \\ \text { USACE } & \text { U.S. Army Corps of Engineers } \\ \text { USGS } & \text { U.S. Geological Survey } \\ \text { WRNO } & \text { Warrendale }\end{array}$


This page is intentionally blank. 


\section{Total Dissolved Gas and Water Temperature in the Lower Columbia River, Oregon and Washington, Water Year 2014}

By Heather M. Bragg and Matthew W. Johnston

\section{Significant Findings}

An analysis of total-dissolved-gas (TDG) and water-temperature data collected at eight fixed monitoring stations on the lower Columbia River in Oregon and Washington in water year 2014 indicated the following:

- All 81 TDG sensor laboratory checks that were performed after field deployment were within plus or minus $( \pm$ ) 0.5-percent saturation of a primary standard.

- After 3-4 weeks of deployment in the river, 68 of 75 TDG sensor field checks were within \pm 1 .0percent saturation of a secondary standard. Six of the field checks greater than \pm 1.0 -percent saturation occurred at the John Day tailwater station, and three of these six checks resulted in periods of deleted data at the station.

- All 77 barometric pressure field checks were within \pm 1 millimeter of mercury of a primary standard, and all 74 water-temperature field checks were within \pm 0.2 degrees Celsius of a secondary standard.

- TDG data were considered complete if they were received in real time and were within 1-percent saturation of the expected value on the basis of calibration data, replicate quality-control measurements, and comparison to river conditions at adjacent stations. For the eight monitoring stations, data completeness ranged from 78.2 to 100 percent.

- All quality-assurance values exceed the criteria established by the U.S. Army Corps of Engineers TDG monitoring plan. Criteria for data completeness (95 percent) were met at six of the eight monitoring stations. Deleted data at the John Day tailwater station and missed transmissions at the Camas station resulted in data completeness below criteria. 


\section{Introduction}

The U.S. Army Corps of Engineers (USACE) operates several dams in the lower Columbia River Basin in Oregon and Washington (fig. 1), which encompasses 259,000 $\mathrm{mi}^{2}$ of the Pacific Northwest. These dams are multipurpose structures that fulfill regional needs for flood control, navigation, irrigation, recreation, hydropower production, fish and wildlife habitat, water-quality maintenance, and municipal and industrial water supply. When water is released through the spillways of these dams (instead of being routed through the turbines to generate electricity), ambient air is entrained in the water. This results in an increase in the concentration of dissolved gases (referred to here as "total dissolved gas," or "TDG”) in the water downstream of the spillways. Concentrations of TDG greater than 110-percent saturation can cause gas-bubble trauma in fish and adversely affect other aquatic organisms (U.S. Environmental Protection Agency, 1986). The USACE regulates streamflow and spill from its dams on the lower Columbia River to minimize the production of excess TDG downstream of the dams, with the additional goal of providing for fish passage through the spillways (rather than through the turbines).

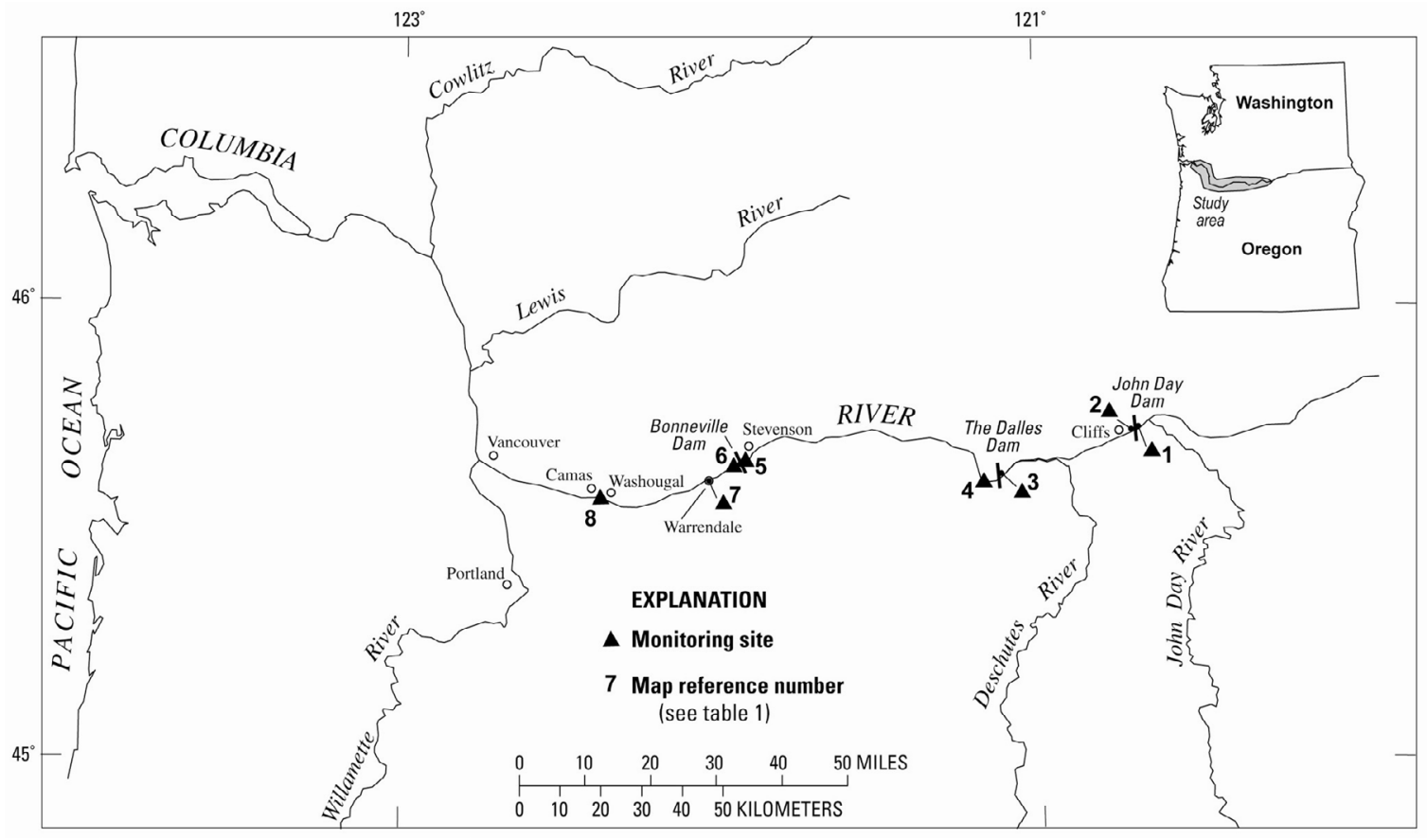

Base map modified from USGS and other digital data, variable scales. Projection unknown.

Figure 1. Location of U.S. Army Corp of Engineers dams and total-dissolved-gas monitoring stations, lower Columbia River, Oregon and Washington, water year 2014.

Real-time TDG and water-temperature data are vital to the USACE for dam operation and for monitoring compliance with environmental regulations. The data are used by water managers to maintain water-quality conditions that facilitate fish passage and ensure their survival in the lower Columbia River. The U.S. Geological Survey (USGS), in cooperation with the Portland District of the USACE, has collected TDG and related data in the lower Columbia River each year since 1996. The hourly values were stored in the USGS database and in a USACE database (U.S. Army Corps of Engineers, 2014). Those data are available online within approximately an hour of collection time, and the current and historical TDG and water-temperature data can be accessed at http://oregon.usgs.gov/projs_dir/pn307.tdg/(accessed October 27, 2014). The USACE database also includes hourly river discharge and spill data. 
Fifteen previous reports, published for water years 1996 and 2000-2013, describe the TDG data, quality-assurance data, and methods of data collection (Tanner and others, 1996; Tanner and Bragg, 2001; Tanner and Johnston, 2001; Tanner and others, 2002, 2003, 2004, 2005, 2006, 2007, 2008, 2009, 2011 , 2012, 2013; Bragg and Johnston, 2014).

This report presents the TDG data and related quality-assurance data that demonstrate the USACE Portland District compliance with the TDG monitoring plan (U.S. Army Corps of Engineers, 2008). To assure the accuracy and integrity of the data needed for managing and modeling TDG in the lower Columbia River, hourly values were reviewed relative to concurrent field measurements, laboratory sensor calibrations, and inter-site comparisons. All deleted or missing data are explained in detail.

\section{Data Collection}

Eight monitoring stations were operated on the lower Columbia River, from the navigation lock of the John Day Dam (river mile [RM] 215.7) to Camas, Washington (RM 121.7) (fig. 1, table 1). Data for water year 2014 (October 1, 2013-September 30, 2014) include hourly measurements of TDG pressure, barometric pressure, water temperature, and sensor depth. Four of the stations (John Day Dam navigation lock, The Dalles Dam forebay, Bonneville Dam forebay, and Camas) were operated from March to September 2014, the period that includes the usual time for dam-spill operations. The stations John Day Dam tailwater, The Dalles Dam tailwater, and Warrendale were operated year-round. Warrendale and Camas remain part of the monitoring program, although TDG data from the stations are no longer part of the USACE spill management program. 
Table 1. Total-dissolved-gas monitoring stations, lower Columbia River, Oregon and Washington, water year 2014.

[Map reference number refers to figure 1; USACE, U.S. Army Corps of Engineers; Columbia River mile locations were determined from U.S. Geological Survey (USGS) 7.5-minute topographic maps; stations in this report are referenced by their abbreviated name or USACE station identifier; ', degree; ', minute; ", second; latitude and longitude are referenced to the North American Datum of 1927; River mile is distance from the mouth of the Columbia River.]

\begin{tabular}{|c|c|c|c|c|c|c|c|}
\hline $\begin{array}{l}\text { Map } \\
\text { reference } \\
\text { number }\end{array}$ & $\begin{array}{l}\text { USACE } \\
\text { station } \\
\text { identifier }\end{array}$ & $\begin{array}{l}\text { River } \\
\text { mile }\end{array}$ & $\begin{array}{l}\text { USGS } \\
\text { station number }\end{array}$ & $\begin{array}{l}\text { USGS station name } \\
\text { (and abbreviated station name) }\end{array}$ & Latitude & Longitude & $\begin{array}{l}\text { Period of } \\
\text { record in water } \\
\text { year } 2014\end{array}$ \\
\hline 1 & JDY & 215.7 & 454314120413701 & $\begin{array}{l}\text { Columbia River at John Day Dam navigation } \\
\text { lock, Washington (John Day navigation lock) }\end{array}$ & $45^{\circ} 43^{\prime} 14^{\prime \prime}$ & $120^{\circ} 41^{\prime} 37^{\prime \prime}$ & $\begin{array}{c}03 / 11 / 14- \\
09 / 15 / 14\end{array}$ \\
\hline 2 & JHAW & 214.7 & 454249120423500 & $\begin{array}{l}\text { Columbia River, right bank, near Cliffs, } \\
\text { Washington (John Day tailwater) }\end{array}$ & $45^{\circ} 42^{\prime} 49^{\prime \prime}$ & $120^{\circ} 42^{\prime} 35^{\prime \prime}$ & $\begin{array}{c}10 / 01 / 13- \\
09 / 30 / 14\end{array}$ \\
\hline 3 & TDA & 192.6 & 453712121071200 & $\begin{array}{l}\text { Columbia River at The Dalles Dam forebay, } \\
\text { Washington (The Dalles forebay) }\end{array}$ & $45^{\circ} 37^{\prime} 12^{\prime \prime}$ & $121^{\circ} 07^{\prime} 12^{\prime \prime}$ & $\begin{array}{c}03 / 12 / 14- \\
09 / 16 / 14\end{array}$ \\
\hline 4 & TDDO & 188.9 & 14105700 & $\begin{array}{l}\text { Columbia River at The Dalles, Oregon (The } \\
\text { Dalles tailwater) }\end{array}$ & $45^{\circ} 36^{\prime} 27^{\prime \prime}$ & $121^{\circ} 10^{\prime} 20^{\prime \prime}$ & $\begin{array}{c}10 / 01 / 13- \\
09 / 30 / 14\end{array}$ \\
\hline 5 & BON & 146.1 & 453845121562000 & $\begin{array}{l}\text { Columbia River at Bonneville Dam forebay, } \\
\text { Washington (Bonneville forebay) }\end{array}$ & $45^{\circ} 38^{\prime} 45^{\prime \prime}$ & $121^{\circ} 56^{\prime} 20^{\prime \prime}$ & $\begin{array}{c}03 / 12 / 14- \\
09 / 24 / 14\end{array}$ \\
\hline 6 & CCIW & 145.9 & 453845121564001 & $\begin{array}{l}\text { Columbia River at Cascade Island, } \\
\text { Washington (Cascade Island) }\end{array}$ & $45^{\circ} 38^{\prime} 45^{\prime \prime}$ & $121^{\circ} 56^{\prime} 40^{\prime \prime}$ & $\begin{array}{c}03 / 26 / 14- \\
09 / 17 / 14\end{array}$ \\
\hline 7 & WRNO & 140.4 & 453630122021400 & $\begin{array}{l}\text { Columbia River, left bank, near Dodson, } \\
\text { Oregon (Warrendale) }\end{array}$ & $45^{\circ} 36^{\prime} 30^{\prime \prime}$ & $122^{\circ} 02^{\prime} 14^{\prime \prime}$ & $\begin{array}{c}10 / 01 / 13- \\
09 / 30 / 14\end{array}$ \\
\hline 8 & CWMW & 121.7 & 453439122223900 & $\begin{array}{l}\text { Columbia River, right bank, at Washougal, } \\
\text { Washington (Camas) }\end{array}$ & $45^{\circ} 34^{\prime} 39^{\prime \prime}$ & $122^{\circ} 22^{\prime} 39^{\prime \prime}$ & $\begin{array}{c}03 / 14 / 14- \\
09 / 18 / 14\end{array}$ \\
\hline
\end{tabular}


Instrumentation at each monitoring station consists of a Hach ${ }^{\circledR}$ Hydrolab water-quality instrument, a Vaisala electronic barometer, a Sutron SatLink2 data-collection platform (DCP), and a power supply. The instruments at each station are powered by a 12-volt battery that is charged by a solar panel or a 120-volt alternating-current line. Measurements are collected, logged, and transmitted every hour. The DCP transmits the four most recent hours of logged data to the Geostationary Operational Environmental Satellite system (Jones and others, 1991). The data are automatically decoded and transferred to the USACE and USGS databases.

Station visits were completed every 4 weeks at the three year-round stations during September 2013 through March 2014, and every 3 weeks at all eight stations during March 2014 to September 2014. The field calibration procedure was as follows: A reference Hydrolab (which was calibrated before the field trip for use as a secondary standard) was deployed alongside the field-deployed Hydrolab for as long as 1 hour to obtain comparison measurements of TDG and water temperature. The field Hydrolab (which had been deployed for 3 or 4 weeks) was then removed and replaced with another Hydrolab that had been recently calibrated in the laboratory. The newly deployed Hydrolab was allowed to equilibrate and the secondary standard was again used to compare TDG and temperature values. The electronic barometer at the monitoring station was calibrated using a portable barometer (NovaLynx 230-M202) that is calibrated annually to National Institute of Standards and Technology (NIST) standards.

During each field visit, the minimum compensation depth was calculated to determine whether the Hydrolab was positioned at an appropriate depth to obtain an accurate measurement of TDG. This minimum compensation depth, which was calculated according to Colt (1984, p. 104), is the depth above which degassing will occur because of decreased hydrostatic pressure. To measure TDG accurately, the Hydrolabs were positioned, whenever possible, at a depth below the calculated minimum compensation depth.

The Hydrolab that was removed from the field after 3 or 4 weeks of deployment was later calibrated in the laboratory. The integrity of the TDG membrane was tested, and the membrane was removed and air-dried. The TDG sensor (without the membrane attached) was calibrated at 0,100, 200, and 300 millimeters of mercury (mm Hg) greater than atmospheric pressure to span the expected range of TDG in the river (approximately 100-, 113-, 126-, and 139-percent saturation, respectively). The membrane was then installed on the TDG sensor and retested.

\section{Data Completeness}

To assure the accuracy and integrity of the TDG data in the lower Columbia River, hourly values were reviewed relative to concurrent field measurements, laboratory instrument calibrations, and daily inter-site comparisons. A summary of the completeness of the TDG percent saturation data is shown in table 2. Data were based on the total number of hourly TDG and barometric pressure data values that could have been collected during the monitoring season. No barometric pressure data were missing when TDG data were available, so data completeness relies on TDG data only. TDG saturation values were considered to meet quality-assurance standards if they were within plus or minus $( \pm) 1$-percent saturation of the expected value. 
Table 2. Completeness and quality of total-dissolved gas data, lower Columbia River, Oregon and Washington, water year 2014.

[TDG, total dissolved gas]

\begin{tabular}{lccc}
\hline \multicolumn{1}{c}{$\begin{array}{c}\text { Abbreviated } \\
\text { station name }\end{array}$} & $\begin{array}{c}\text { Planned } \\
\text { monitoring } \\
\text { (hours) }\end{array}$ & $\begin{array}{c}\text { Number of } \\
\text { missing or deleted } \\
\text { hourly values }\end{array}$ & $\begin{array}{c}\text { Percentage of real-time } \\
\text { TDG data passing } \\
\text { quality assurance } \\
\text { criteria }\end{array}$ \\
\hline $\begin{array}{l}\text { John Day navigation lock } \\
\text { (JDY) }\end{array}$ & 4,510 & 1 & 100 \\
$\begin{array}{l}\text { John Day tailwater } \\
\text { (JHAW) }\end{array}$ & 8,760 & 1,517 & 82.7 \\
$\begin{array}{l}\text { The Dalles forebay } \\
\text { (TDA) }\end{array}$ & 4,511 & 141 & 96.9 \\
$\begin{array}{l}\text { The Dalles tailwater } \\
\text { (TDDO) }\end{array}$ & 8,760 & 6 & 99.9 \\
$\begin{array}{l}\text { Bonneville forebay } \\
\text { (BON) }\end{array}$ & 4,701 & 1 & 100 \\
$\begin{array}{l}\text { Cascade Island } \\
\text { (CCIW) }\end{array}$ & 4,199 & 4 & 99.9 \\
$\begin{array}{l}\text { Warrendale } \\
\text { (WRNO) } \\
\text { Camas } \\
\text { (CWMW) }\end{array}$ & 8,760 & 31 & 99.6 \\
\hline
\end{tabular}

Periods for which substantial spans of TDG data were either missing from the database or were later deleted from the database because they did not meet quality-assurance standards are listed in table 3. Failed instrument communications and datalogger transmissions were the most common causes of missing data, although most of those data were recovered and later entered into the databases. Most of the deleted data were from the John Day tailwater station. Review of the field checks and in-stream data indicated erroneously low TDG values during three periods: October-November 2013, August 2014, and September 2104. Additional data collection and analysis are ongoing to determine the cause of the low data values. 
Table 3. Periods of missing real-time total-dissolved-gas (TDG) data, lower Columbia River, Oregon and Washington, water year 2014.

[USACE (U.S. Army Corps of Engineers) station identifier: JHAW, John Day tailwater; TDA The Dalles forebay; TDDO, The Dalles tailwater; WRNO, Warrendale; CWMW, Camas]

\begin{tabular}{rll}
\hline \multicolumn{1}{c}{ Date } & $\begin{array}{c}\text { USACE } \\
\text { station } \\
\text { identifier }\end{array}$ & \\
\hline $\begin{array}{l}\text { 10/01/13-11/08/13 } \\
\text { 08/07/14-08/26/14 } \\
09 / 15 / 14-09 / 21 / 14\end{array}$ & JHAW & Erroneously low TDG values \\
\hline $\begin{array}{l}\text { 05/15/14-05/17/14 } \\
05 / 28 / 14-06 / 02 / 14\end{array}$ & TDA & $\begin{array}{l}\text { Failed communication between the water-quality instrument and } \\
\text { datalogger }\end{array}$ \\
\hline $03 / 12 / 14$ & TDDO & $\begin{array}{l}\text { Water-quality instrument removed from deployment pipe during } \\
\text { maintenance }\end{array}$ \\
\hline $\begin{array}{l}02 / 09 / 14 \\
02 / 10 / 14\end{array}$ & WRNO & Failed satellite transmissions owing to inclement weather \\
\hline $\begin{array}{l}03 / 31 / 14-04 / 02 / 14 \\
06 / 30 / 14-07 / 24 / 14\end{array}$ & CWMW & Failed satellite transmissions; data were recovered \\
\hline $\begin{array}{l}07 / 25 / 14-07 / 29 / 14 \\
08 / 16 / 14-08 / 25 / 14\end{array}$ & CWMW & Ruptured membrane on TDG sensor \\
\hline $07 / 29 / 14-07 / 30 / 14$ & CWMW & Datalogger malfunction \\
\hline
\end{tabular}

\section{Quality-Assurance Data}

The collection of accurate data for TDG, barometric pressure, and water temperature involves several quality-assurance procedures, including side-by-side instrument comparisons in the field, sensor calibrations in the laboratory, daily checks of the data, and data review and archiving. The results of the quality-assurance procedures for water year 2014 are presented in this section.

After field deployment for 3 or 4 weeks, the TDG instruments were calibrated in the laboratory. First, the sensor was tested, with the gas-permeable membrane in place, for response to supersaturated conditions. The membrane was then removed from the sensor and allowed to dry for at least 24 hours. Before replacing the membrane, the TDG sensor was examined independently by comparing the reading of the TDG sensor to barometric pressure (100-percent saturation). Using a certified digital pressure gage (primary standard), comparisons were also made at pressures of 100, 200, and $300 \mathrm{~mm} \mathrm{Hg}$ greater than barometric pressure (approximately 113-, 126-, and 139-percent saturation, respectively). The accuracy of the TDG sensors was calculated as the difference between the primary standard and the TDG sensor reading (expected minus actual) for each of the four test conditions divided by the barometric pressure and multiplied by 100 to obtain a percentage difference. Of the 81 laboratory checks that were performed on instruments after field deployment, all were within \pm 0.5 -percent saturation (fig. 2). 


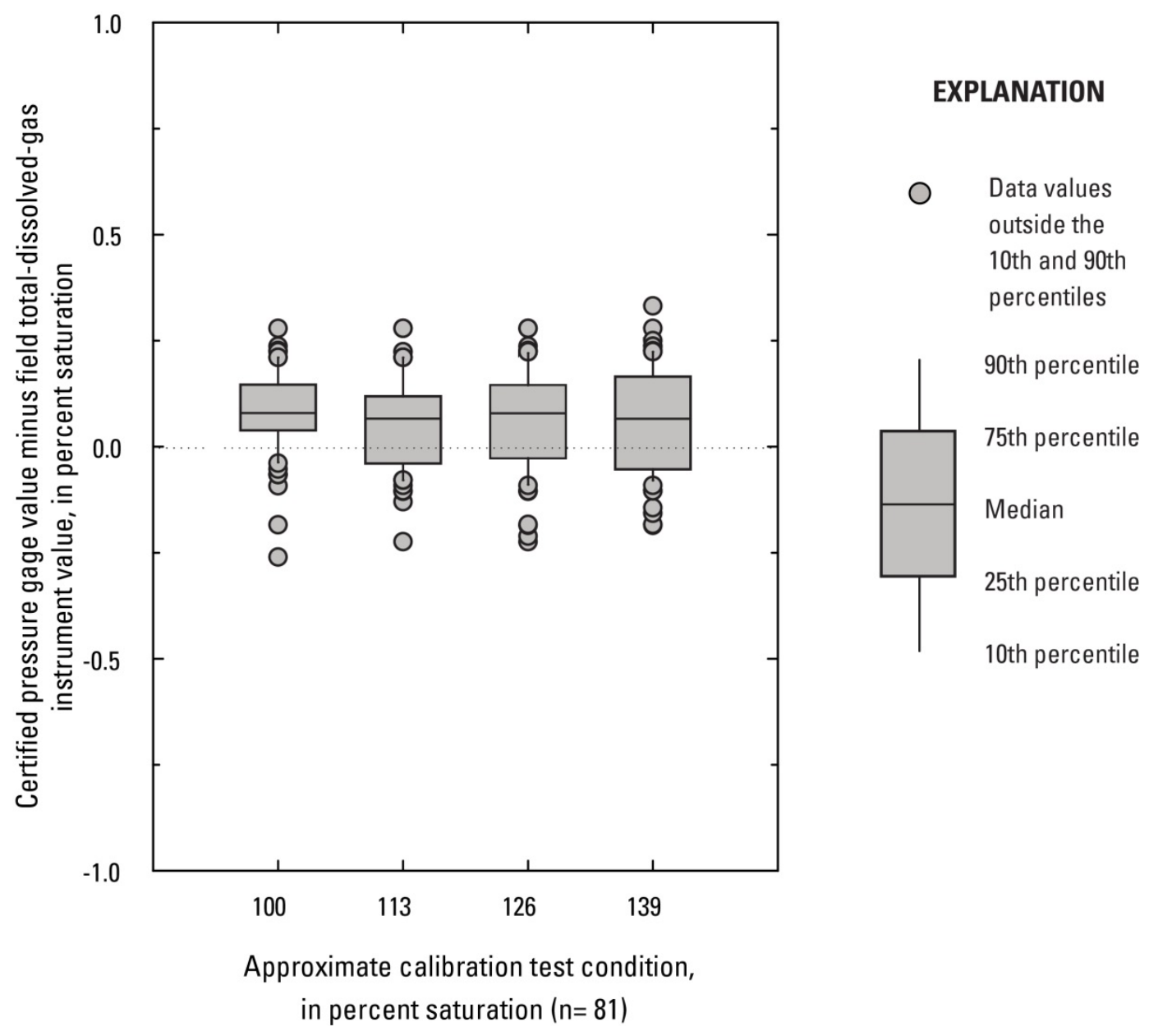

Figure 2. Boxplot showing accuracy of total-dissolved-gas sensors in the laboratory after 3 or 4 weeks of field deployment at eight monitoring stations in the lower Columbia River, Oregon and Washington, water year 2014 (number of comparison values $=81$ ).

The differences in barometric pressure, water temperature, and TDG between the secondary standard instruments and the station monitors at the end of their field deployment were measured and recorded as part of every field inspection and calibration procedure. These differences, calculated as the secondary standard values minus the field instrument values, were used to compare and quantify the accuracy and precision between the two instruments. For water temperature and TDG, the measurements were made with the secondary standard (a recently calibrated Hydrolab) positioned alongside the Hydrolab deployed in the river. A digital barometer (NIST certified through April 2015) served as the primary standard for barometric pressure. The distribution of quality-assurance data for each of the three parameters from the eight stations is shown in figures 3,4 , and 5 .

Comparisons of the digital barometer and the field barometers are shown in figure 3 . All of the field values were within $1 \mathrm{~mm} \mathrm{Hg}$ of standard values. The secondary standard temperature sensor and the field temperature sensor results are presented in figure 4 . All differences were within $0.2^{\circ} \mathrm{C}$. 


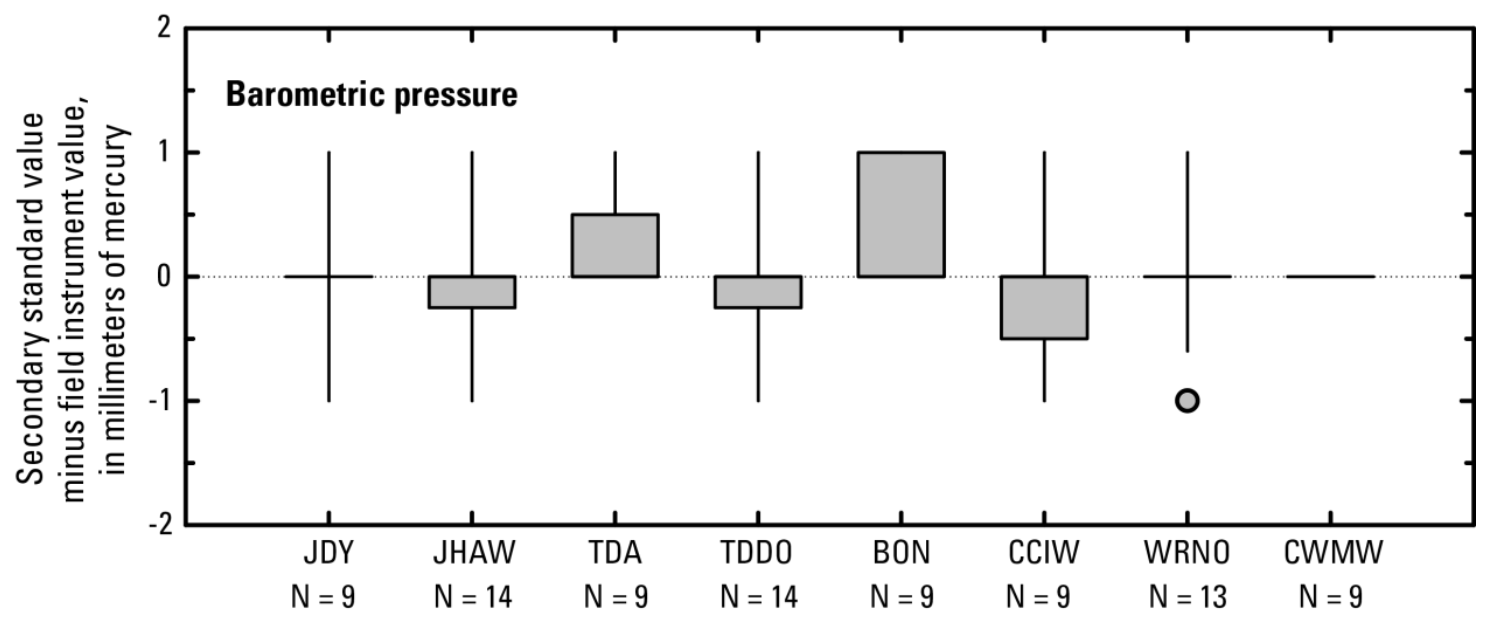

Site identifier and number of samples

Figure 3. Boxplot showing difference between the secondary standard and the field barometers in the field after 3 or 4 weeks of deployment at eight stations in the lower Columbia River, Oregon and Washington, water year 2014. See figure 2 for explanation of boxplots and table 1 for definitions of station identifiers.

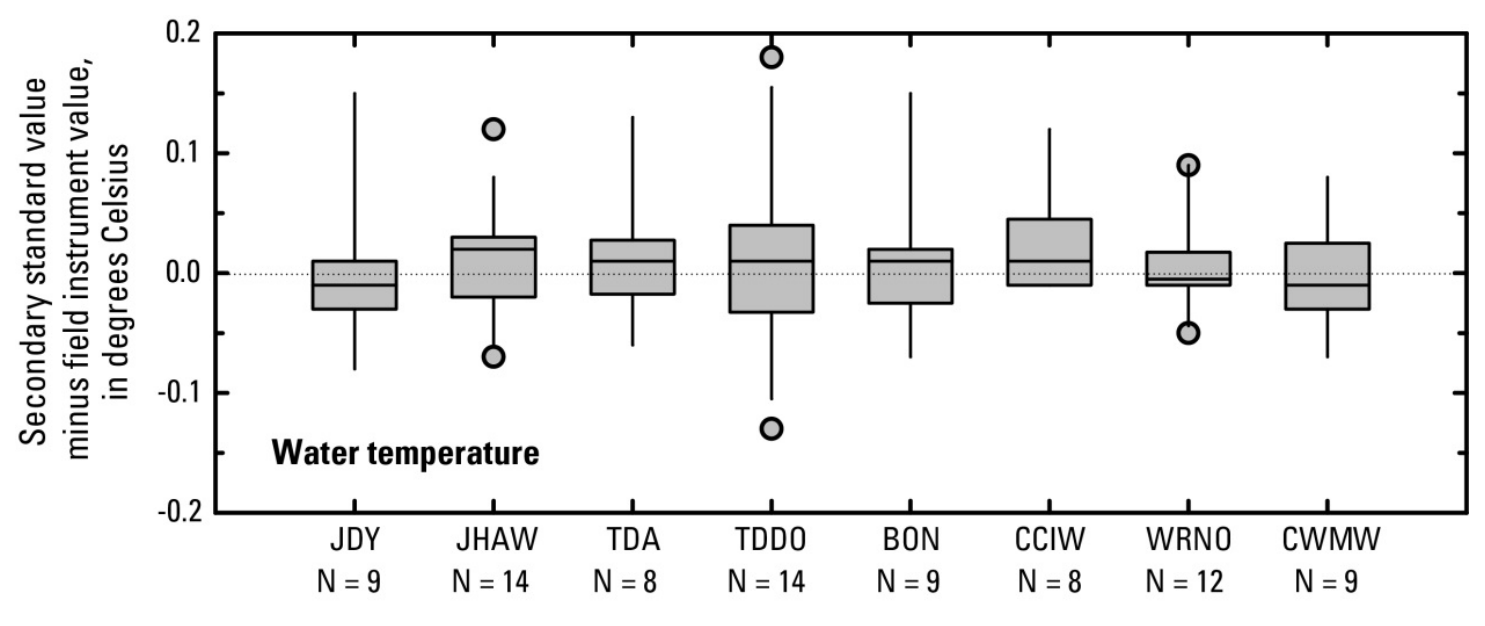

Site identifier and number of samples

Figure 4. Boxplot showing difference between the secondary standard and the field temperature instruments in the field after 3 or 4 weeks of deployment at eight stations in the lower Columbia River, Oregon and Washington, water year 2014. See figure 2 for explanation of boxplots and table 1 for definitions of station identifiers.

Differences between the secondary standard TDG sensor and the field TDG sensors were calculated following equilibration of the secondary standard instrument to the site conditions before removing the field instrument. The side-by-side equilibrium was considered complete after a minimum of 20 minutes when the TDG values for each sensor remained constant for 3-5 minutes. Excluding the John Day tailwater station, only 1 of the 61 TDG field checks indicated a saturation difference greater than \pm 1.0 percent (fig. 5). That difference (+2.0 percent) was recorded at Warrendale and was likely the result of an incomplete equilibration of the reference Hydrolab during changing in-stream conditions. No data were deleted as a result of that field check. Of the 14 field checks at the John Day tailwater station, two were $+1-2$ percent and four were $+2-5$ percent. Three of the checks resulted in periods of deleted data (table 3 ). 
The three other checks seemed to be the result of incomplete reference Hydrolab equilibrations or changing in-stream conditions rather than true differences, and no data were deleted.

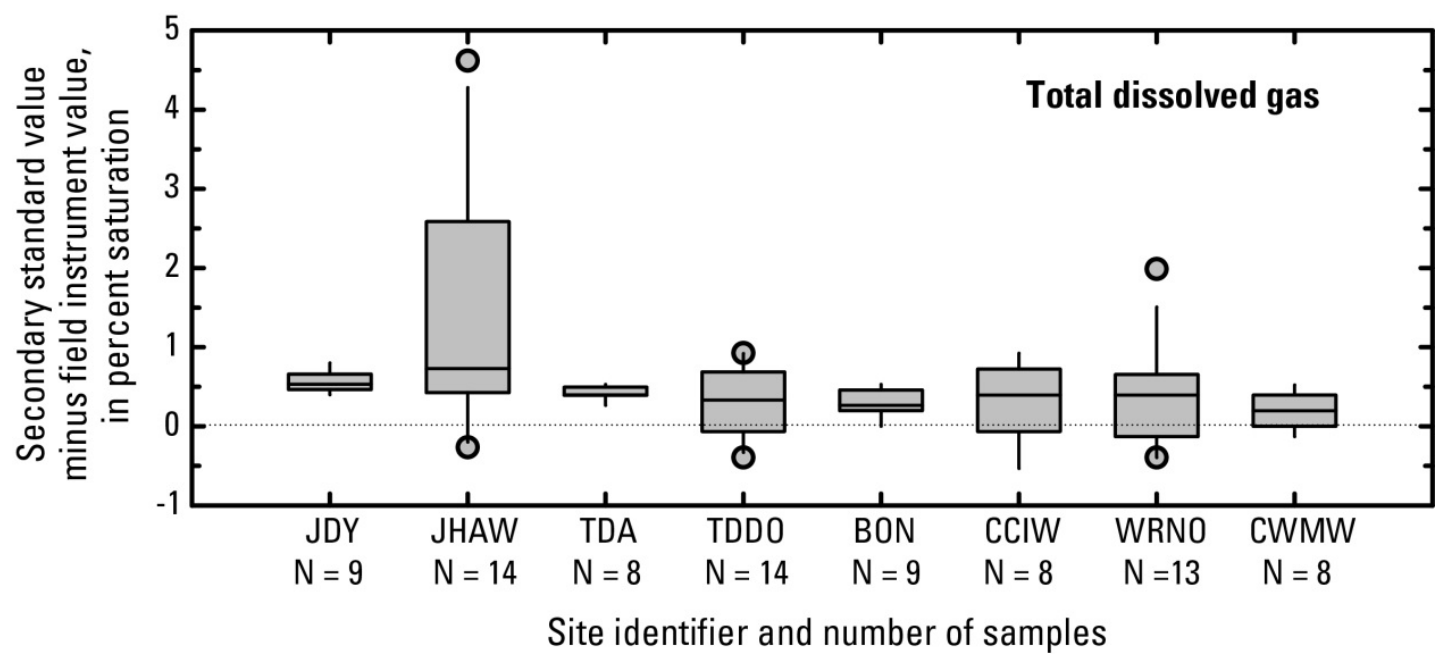

Figure 5. Boxplot showing difference between the secondary standard and the field total-dissolved-gas instruments in the field after 3 or 4 weeks of deployment at eight stations in the lower Columbia River, Oregon and Washington, water year 2014. See figure 2 for explanation of boxplots and table 1 for definitions of station identifiers.

\section{Effects of Spill on Total-Dissolved-Gas Saturation}

The relation between spill discharge at the dams and TDG at the corresponding tailwater station or stations is shown for John Day Dam (fig. 6), The Dalles Dam (fig. 7), and Bonneville Dam (fig. 8). For spill between approximately 25,000 and 70,000 ft ${ }^{3} / \mathrm{s}$, the TDG saturation downstream of John Day Dam remained relatively level or slightly decreasing between 111 percent and 116 percent. For spill greater than $70,000 \mathrm{ft}^{3} / \mathrm{s}$, the TDG saturation increased steadily with greater spill. At the stations downstream of The Dalles Dam and Bonneville Dam, the TDG saturation values generally increased with greater spill over the entire range of values. 


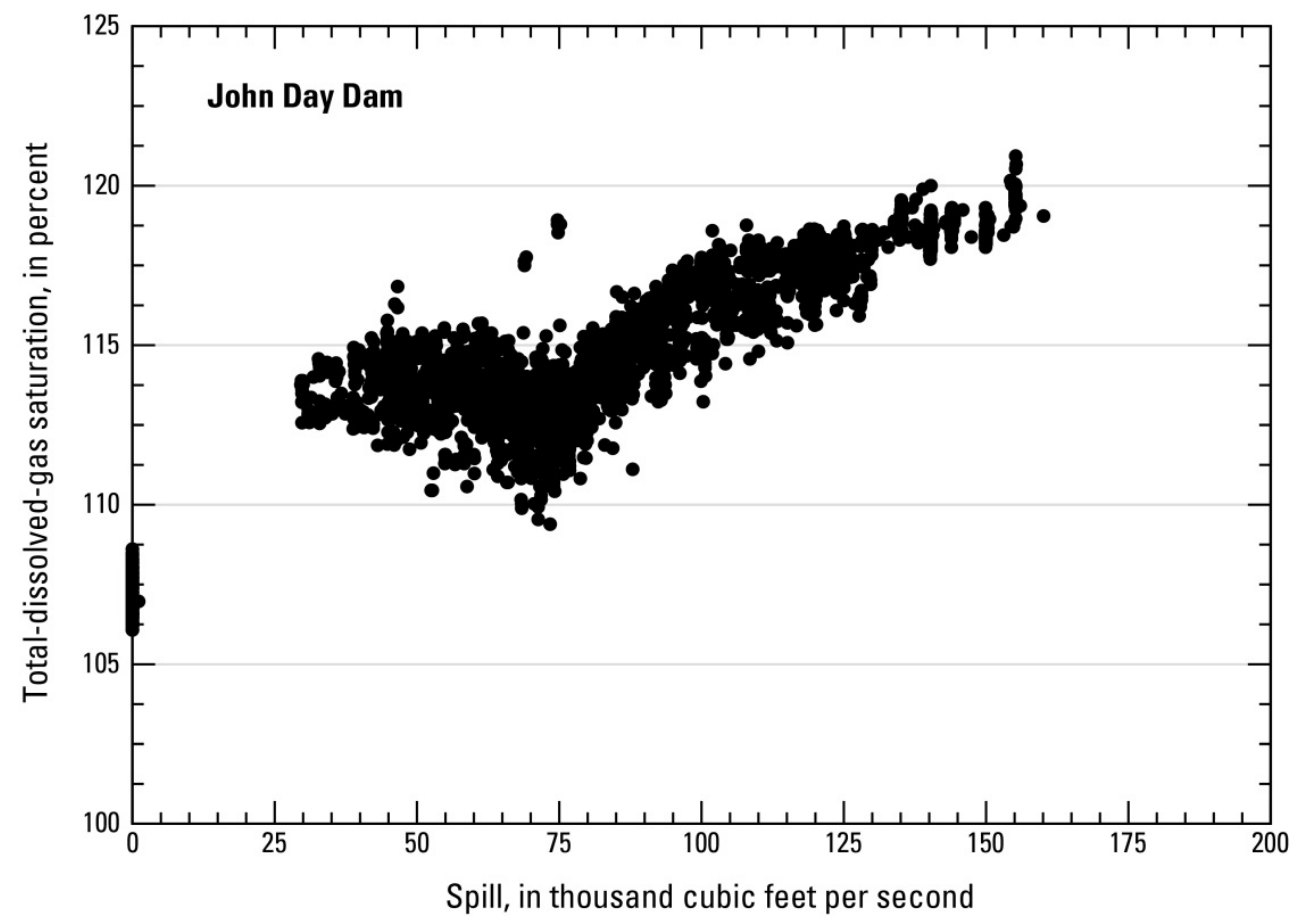

Figure 6. Graph showing relation of total-dissolved-gas saturation downstream of John Day Dam and spill from John Day Dam, lower Columbia River, Oregon and Washington, April 1-August 31, 2014.

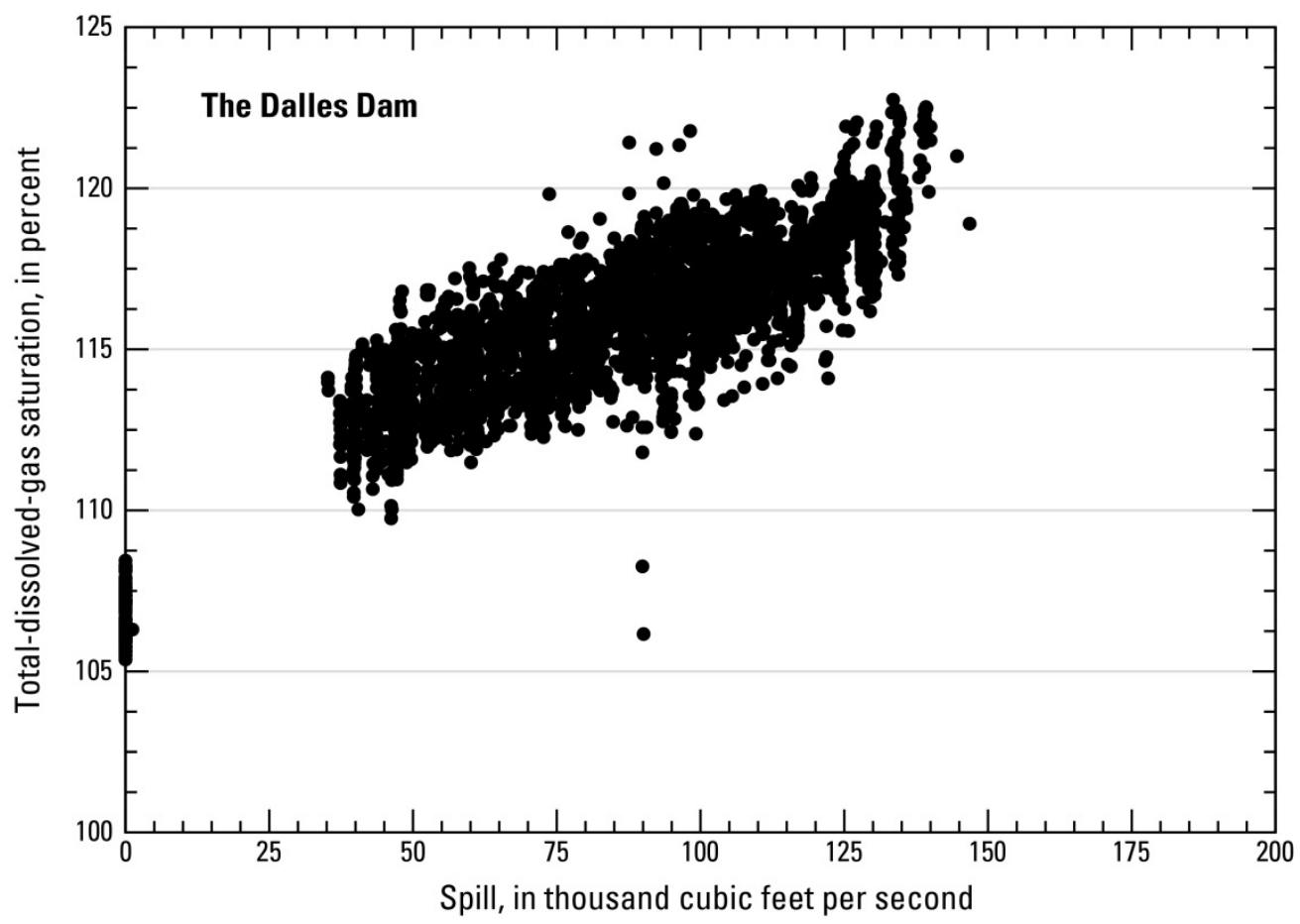

Figure 7. Graph showing relation of total-dissolved-gas saturation downstream of The Dalles Dam and spill from The Dalles Dam, lower Columbia River, Oregon and Washington, April 1-August 31, 2014. 


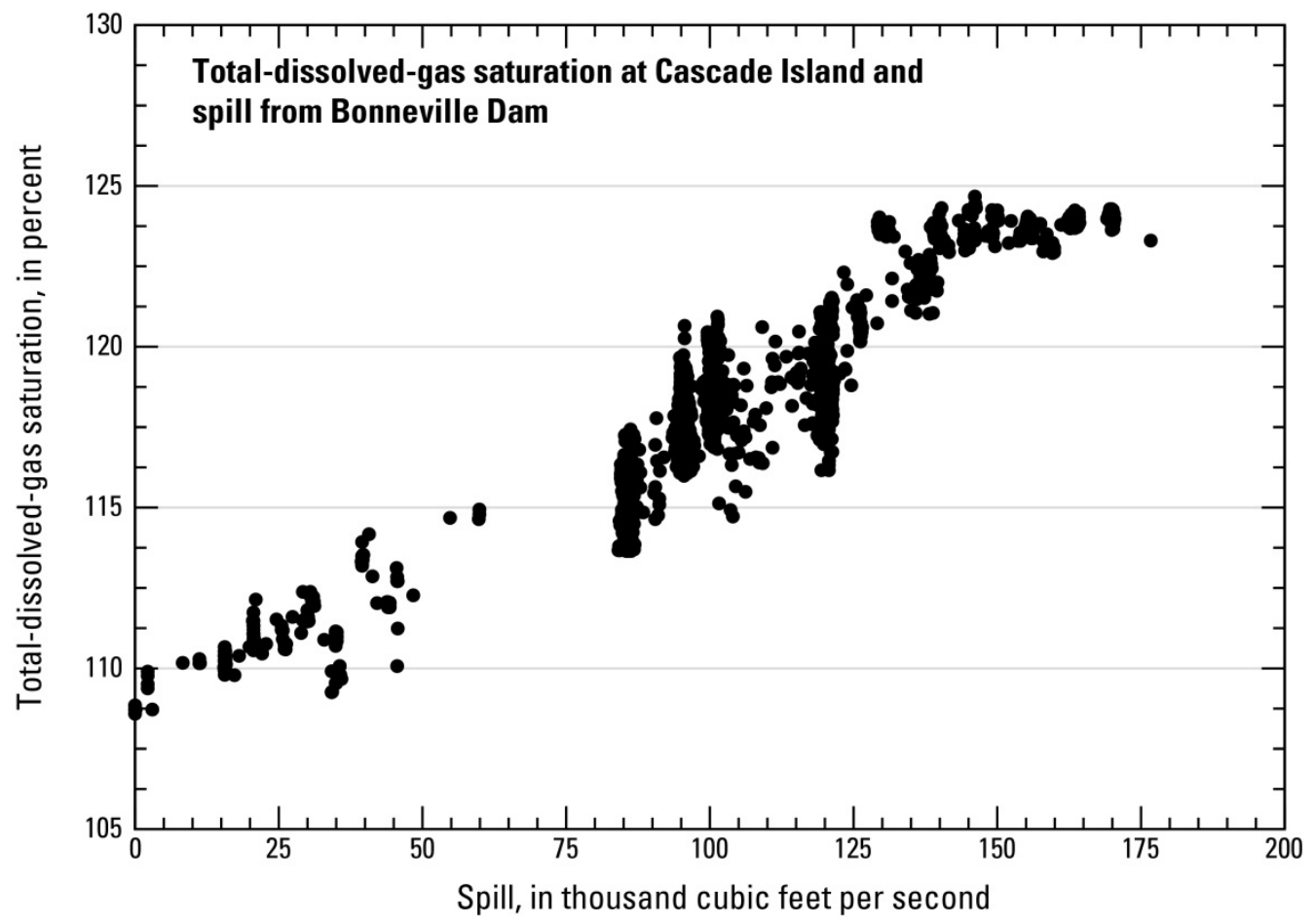

Figure 8. Graph showing relation of total-dissolved-gas saturation downstream of Bonneville Dam at Cascade Island and spill from Bonneville Dam, lower Columbia River, Oregon and Washington, April 1-August 31, 2014. 


\section{Total-Dissolved-Gas and Water-Temperature Data}

The distribution of hourly TDG values for the 2014 spill season (April 1-August 31, 2014) is shown in figure 9. Time-series plots of the hourly TDG percent saturation and the spill at the closest upstream dam are shown in figures 10-17.

The hourly values for water temperature are shown in figures 18-22. Water temperatures at the forebay stations were approximately equal to the temperatures at the tailwater stations, except during short periods at the John Day Dam stations and at the Bonneville Dam forebay and Warrendale stations.

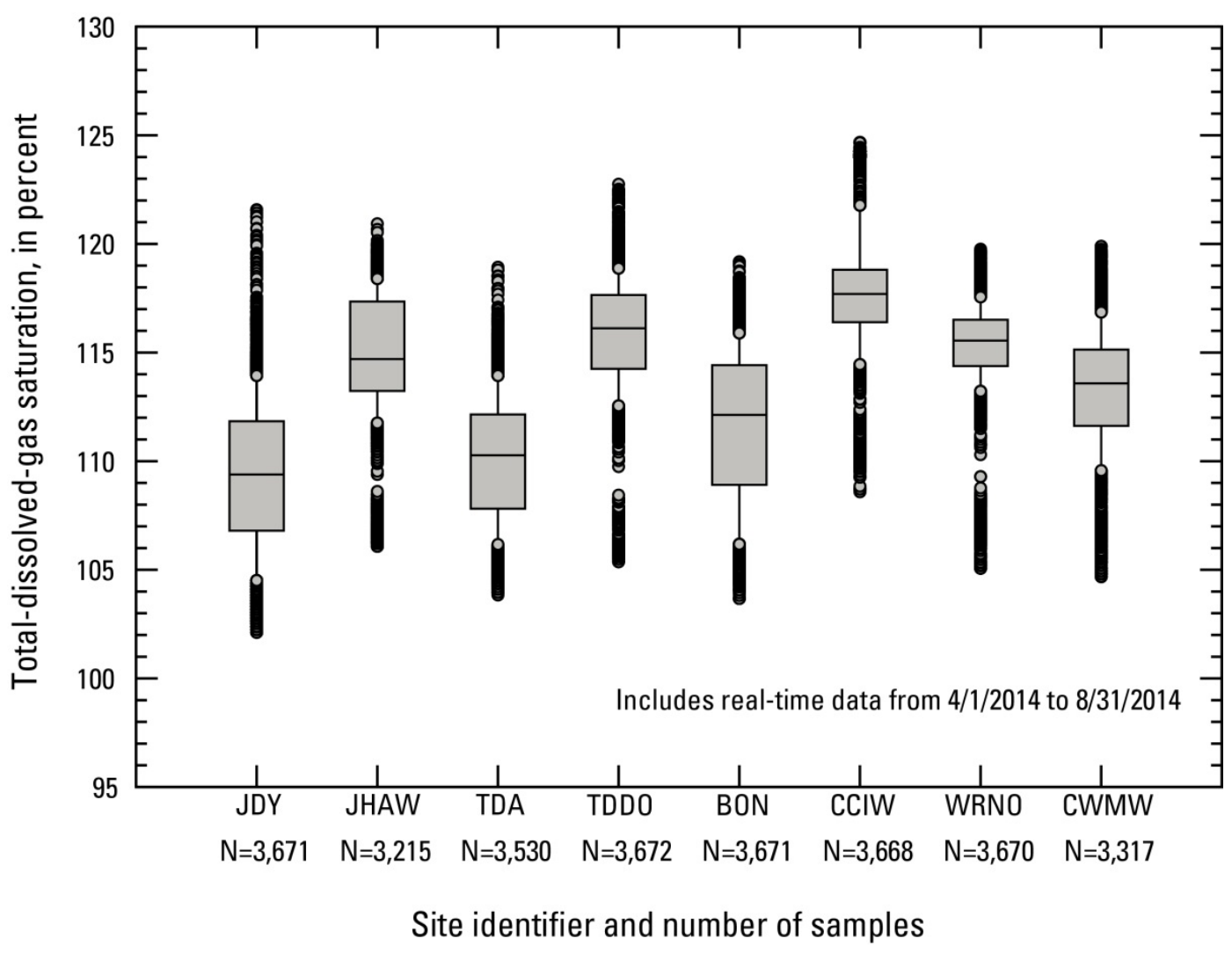

Figure 9. Boxplot showing distributions of hourly total-dissolved-gas data, lower Columbia River, Oregon and Washington, April 1-August 31, 2014. See figure 2 for explanation of boxplots and table 1 for definitions of station identifiers. 

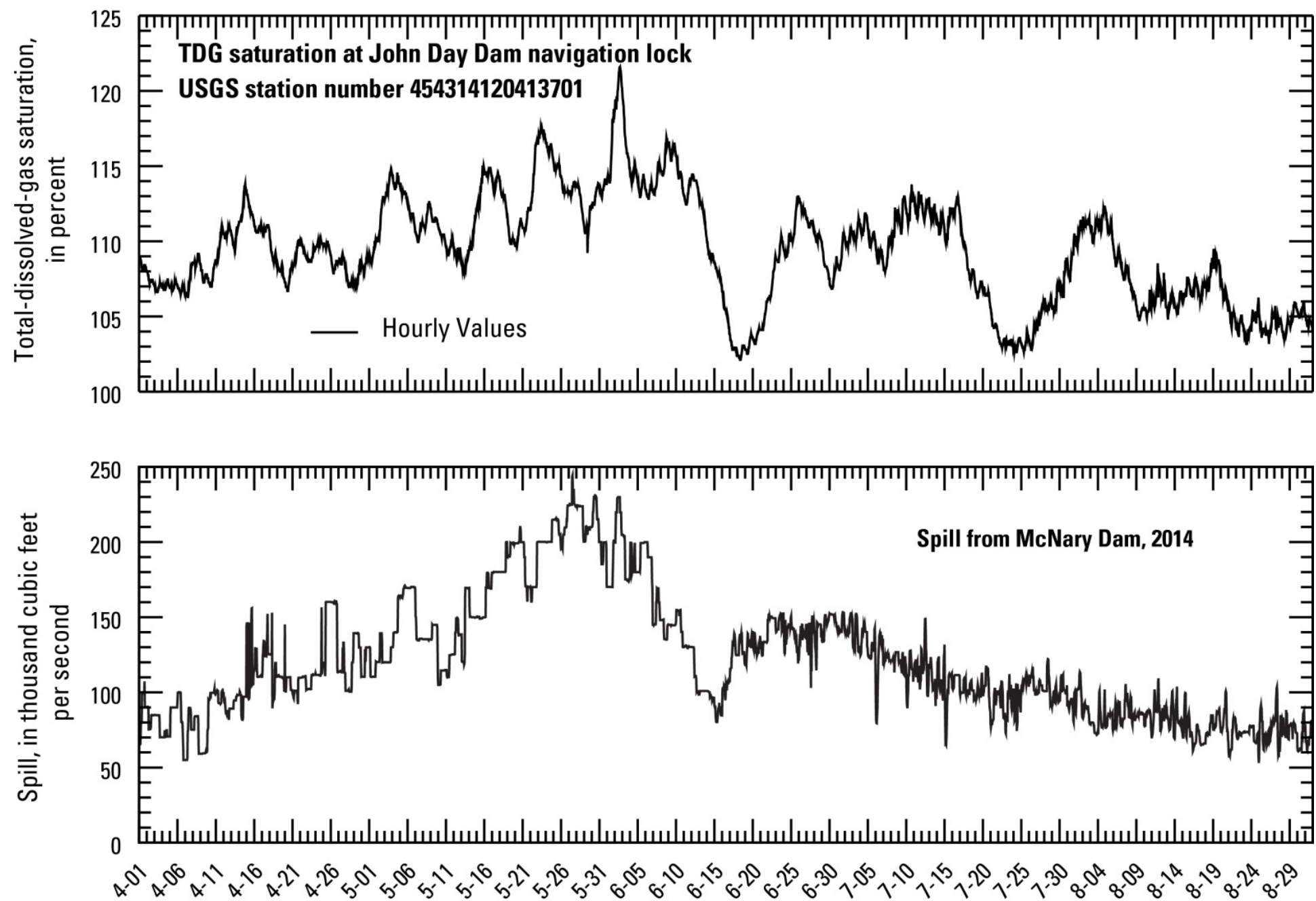

Date in 2014

Figure 10. Graphs showing total-dissolved-gas (TDG) saturation at John Day Dam navigation lock and spill from McNary Dam (76 river miles upstream of John Day Dam), lower Columbia River, Oregon and Washington, April 1-August 31, 2014. 

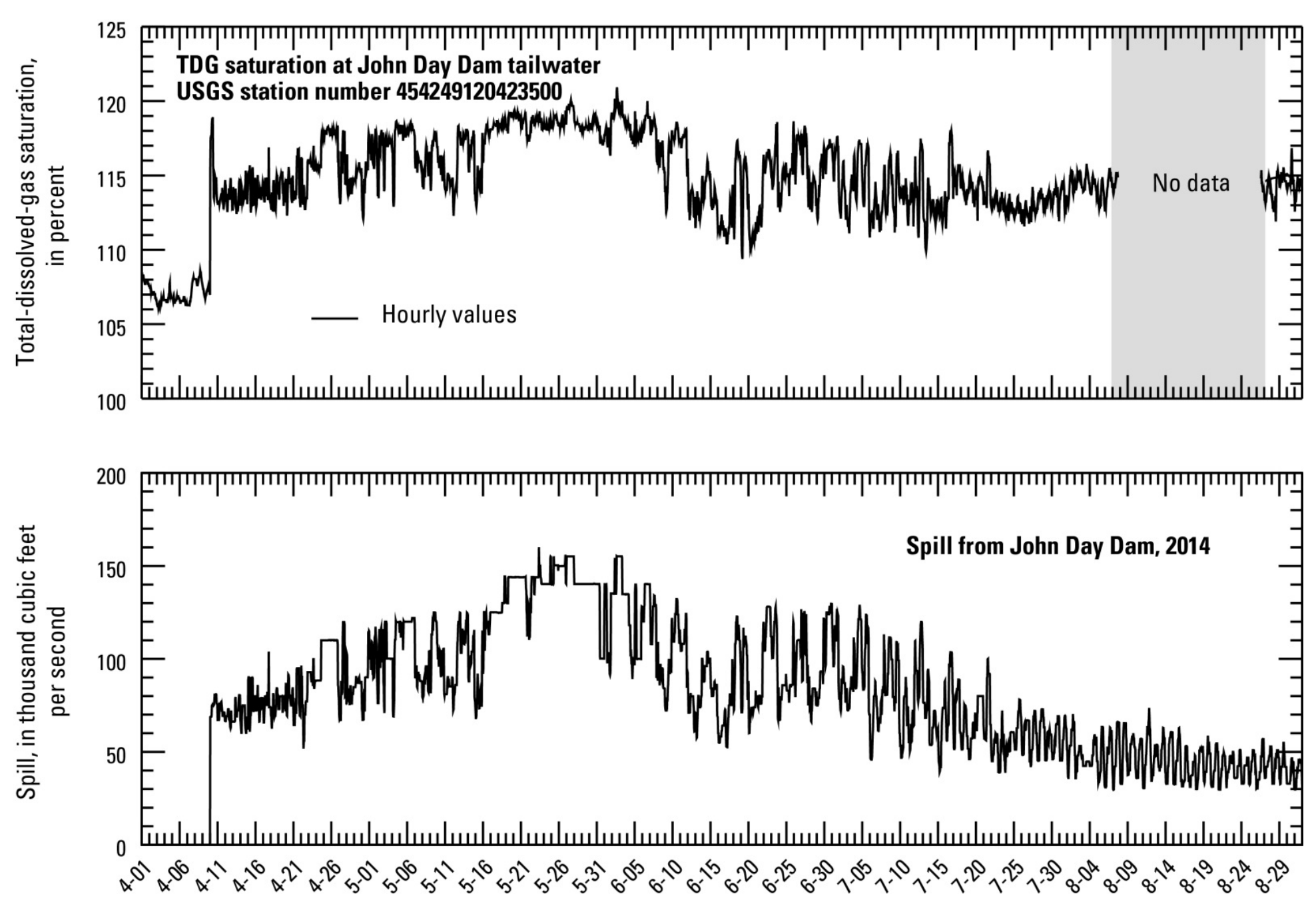

Date in 2014

Figure 11. Graphs showing total-dissolved-gas (TDG) saturation at John Day Dam tailwater and spill from John Day Dam, lower Columbia River, Oregon and Washington, April 1-August 31, 2014. 

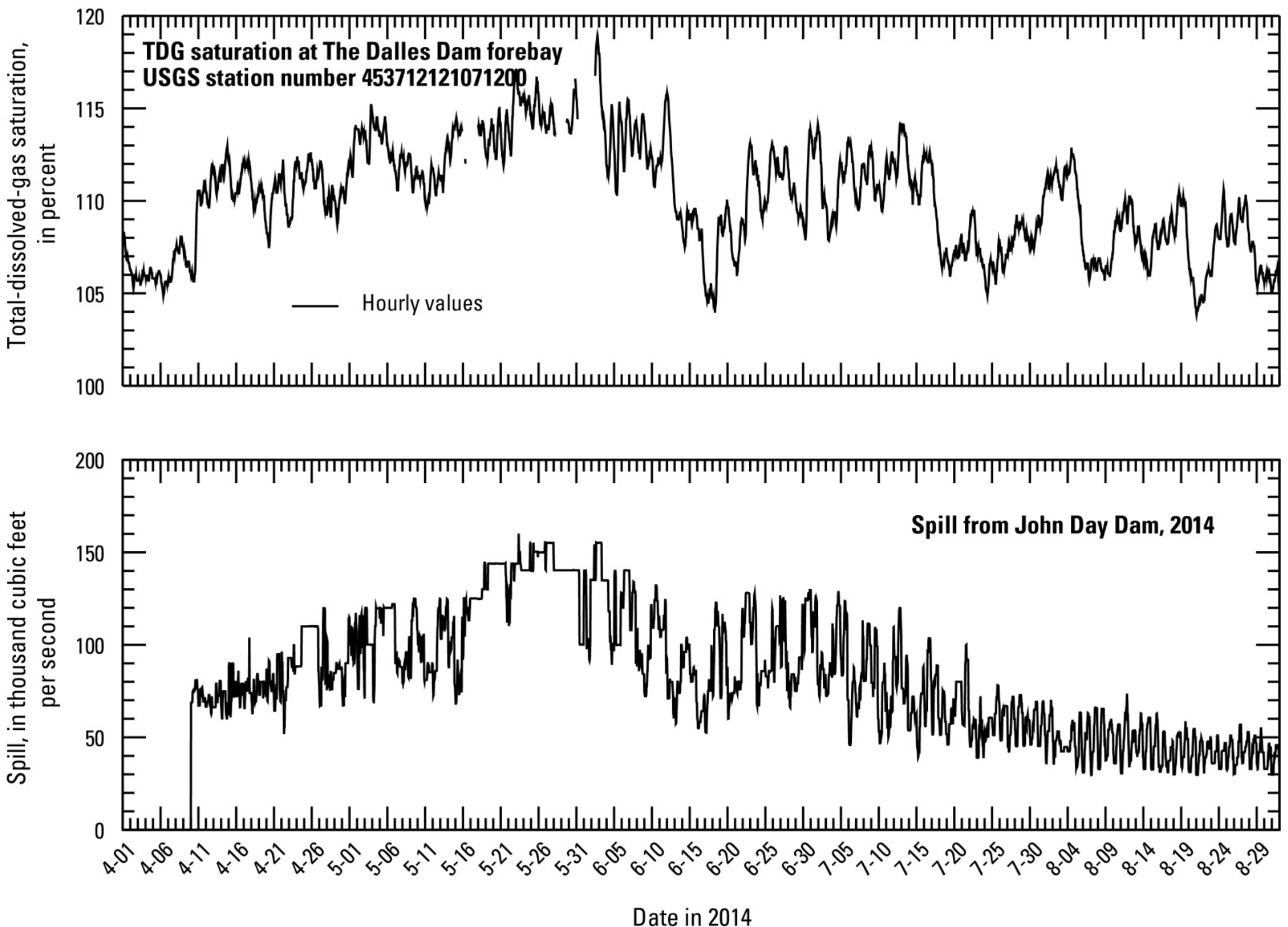

Figure 12. Graphs showing total-dissolved-gas (TDG) saturation at The Dalles Dam forebay and spill from John Day Dam, lower Columbia River, Oregon and Washington, April 1-August 31, 2014. 

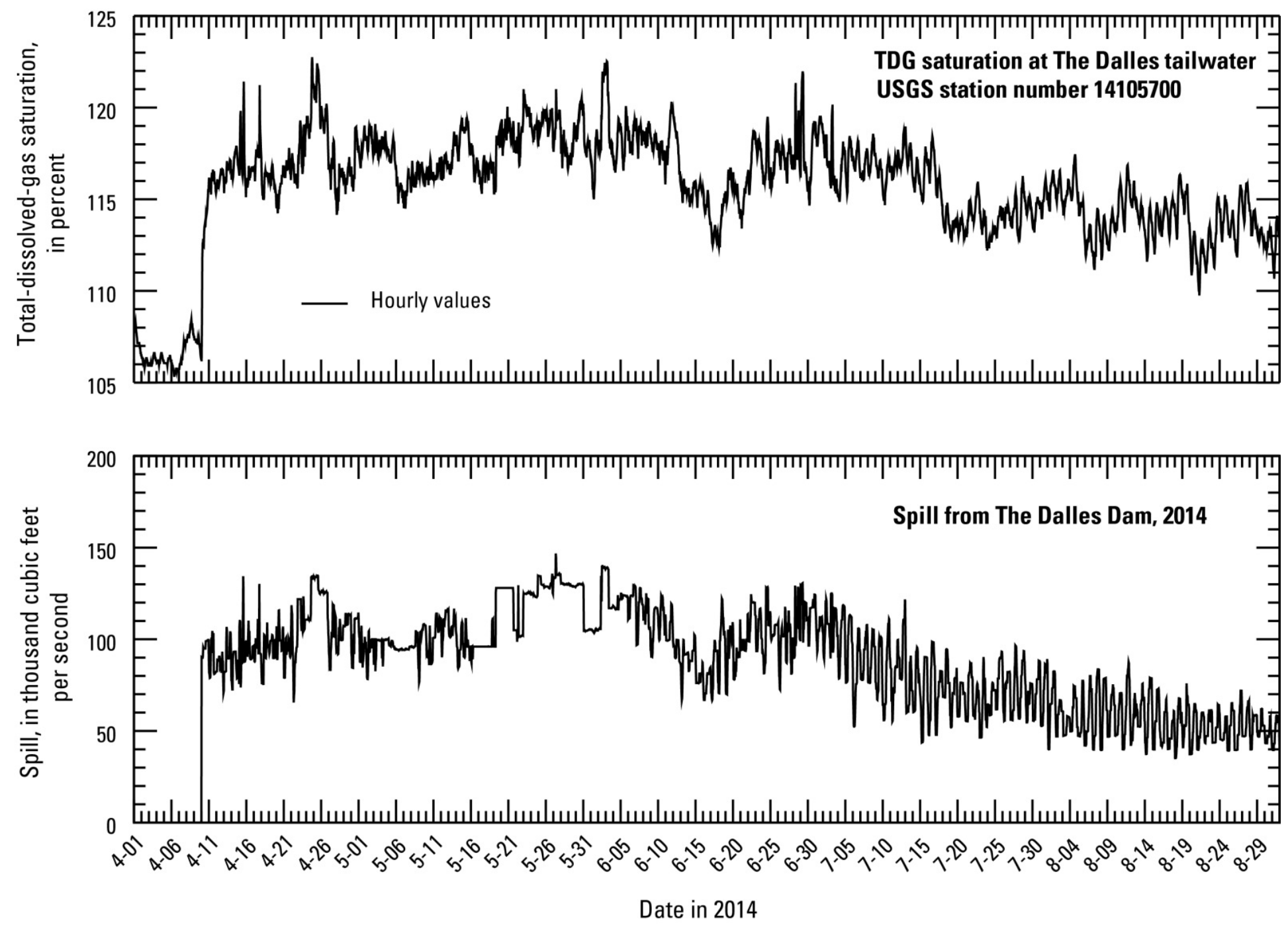

Figure 13. Graphs showing total-dissolved-gas (TDG) saturation at The Dalles Dam tailwater and spill from The Dalles Dam, lower Columbia River, Oregon and Washington, April 1-August 31, 2014. 

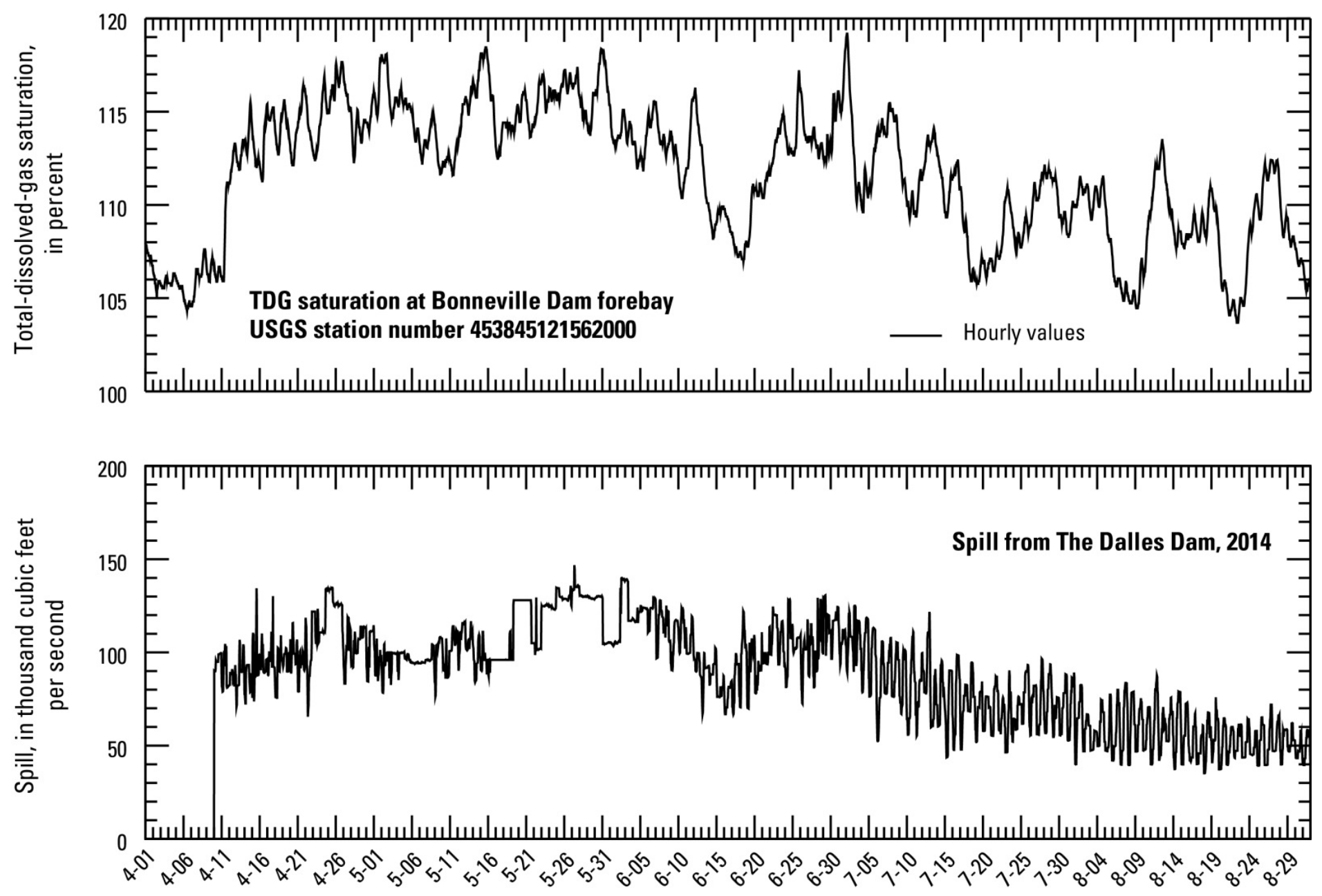

\section{Date in 2014}

Figure 14. Graphs showing total-dissolved-gas (TDG) saturation at Bonneville Dam forebay and spill from The Dalles Dam, lower Columbia River, Oregon and Washington, April 1-August 31, 2014. 

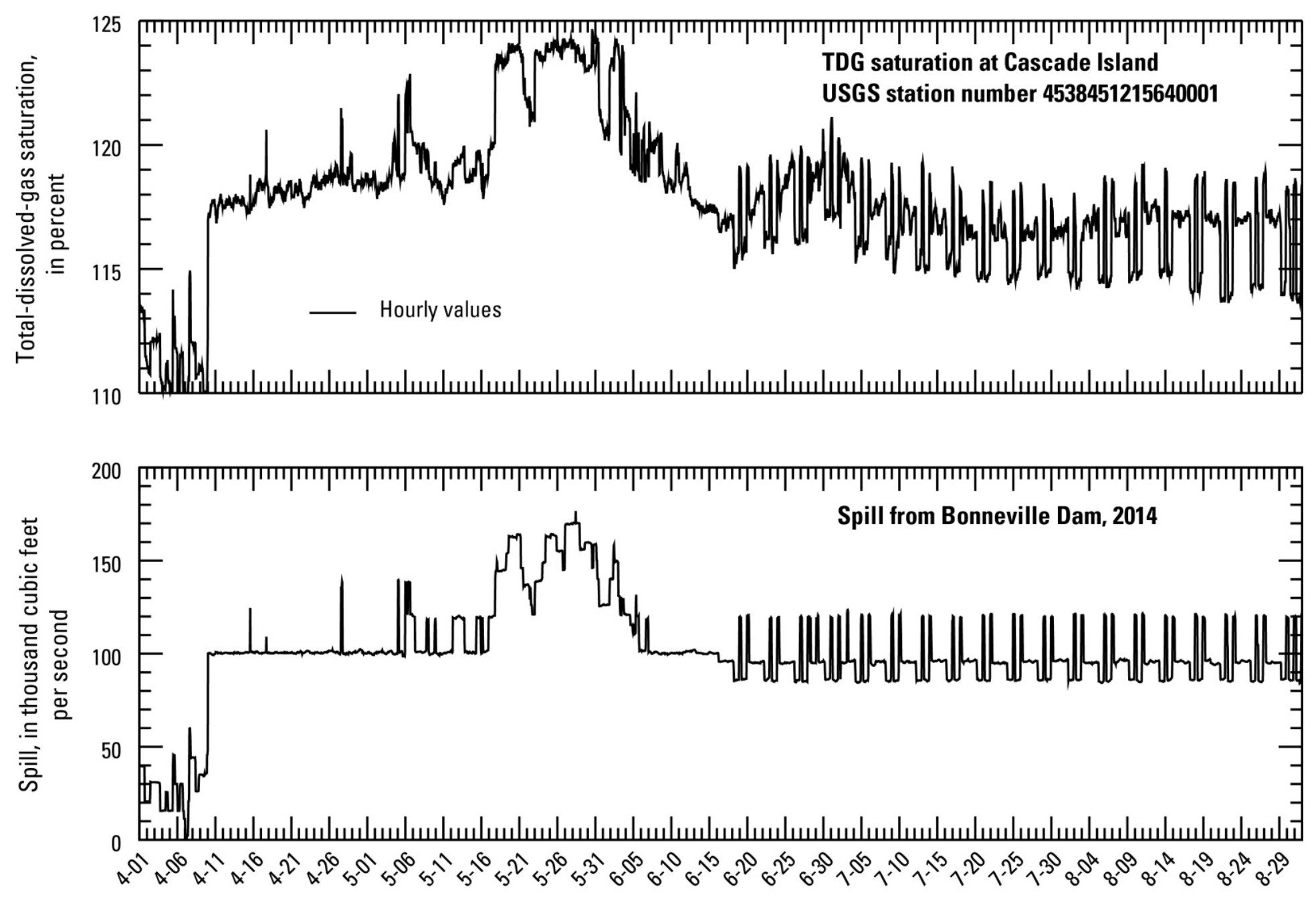

Date in 2014

Figure 15. Graphs showing total-dissolved-gas (TDG) saturation at Cascade Island and spill from Bonneville Dam, lower Columbia River, Oregon and Washington, April 1-August 31, 2014. 

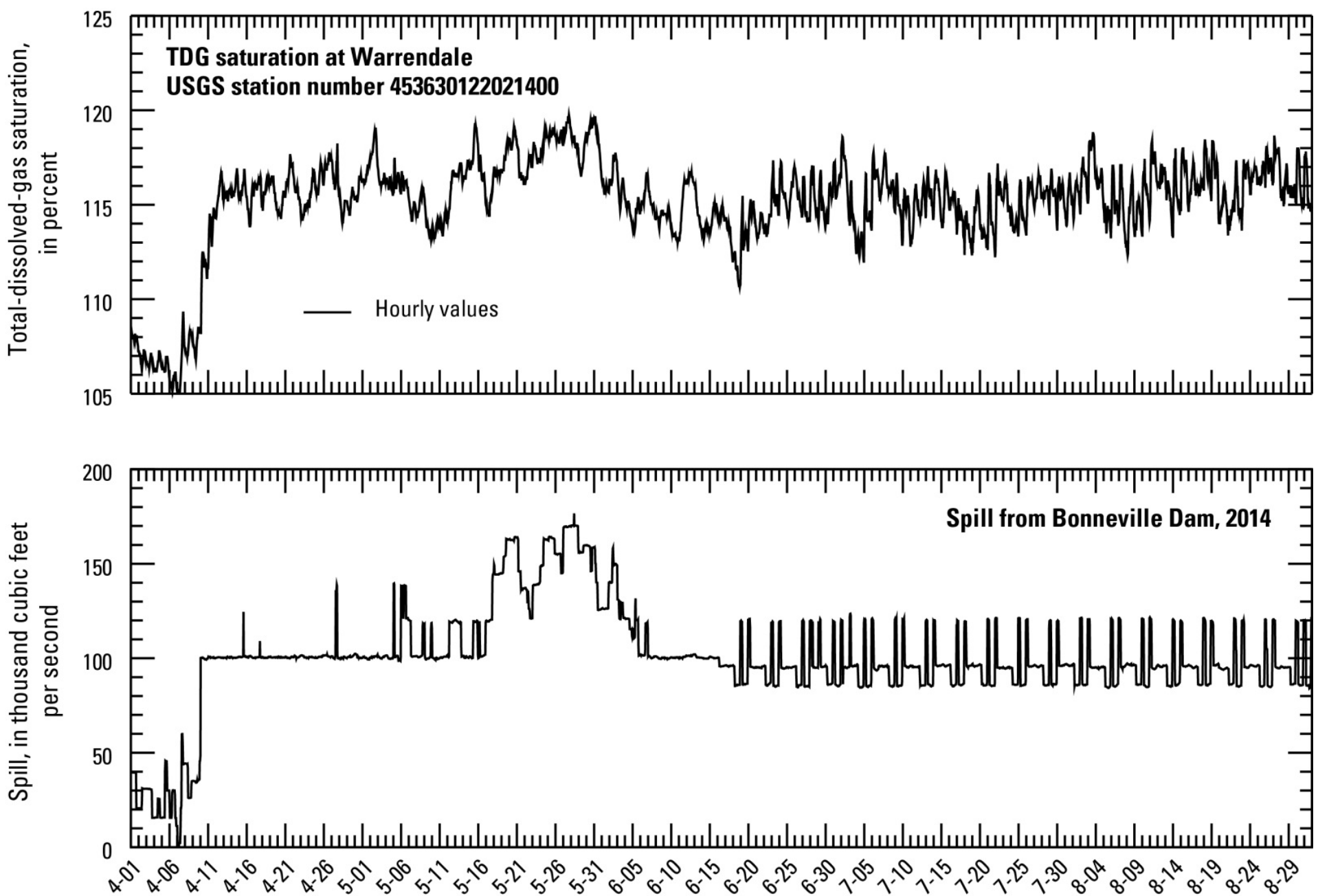

Date in 2014

Figure 16. Graphs showing total-dissolved-gas (TDG) saturation at Warrendale and spill from Bonneville Dam, lower Columbia River, Oregon and Washington, April 1-August 31, 2014. 

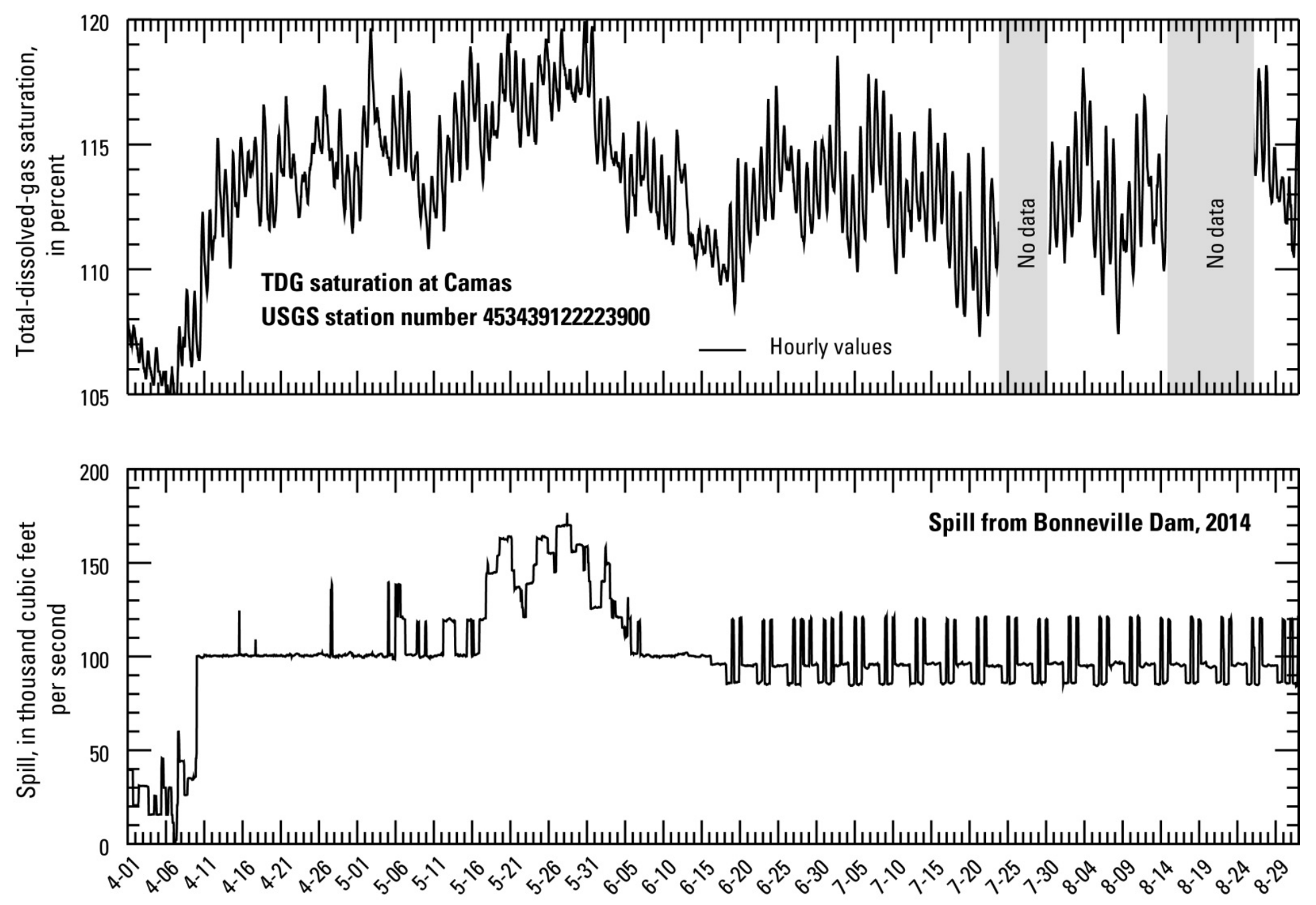

Date in 2014

Figure 17. Graphs showing total-dissolved-gas (TDG) saturation at Camas and spill from Bonneville Dam, lower Columbia River, Oregon and Washington, April 1-August 31, 2014. 


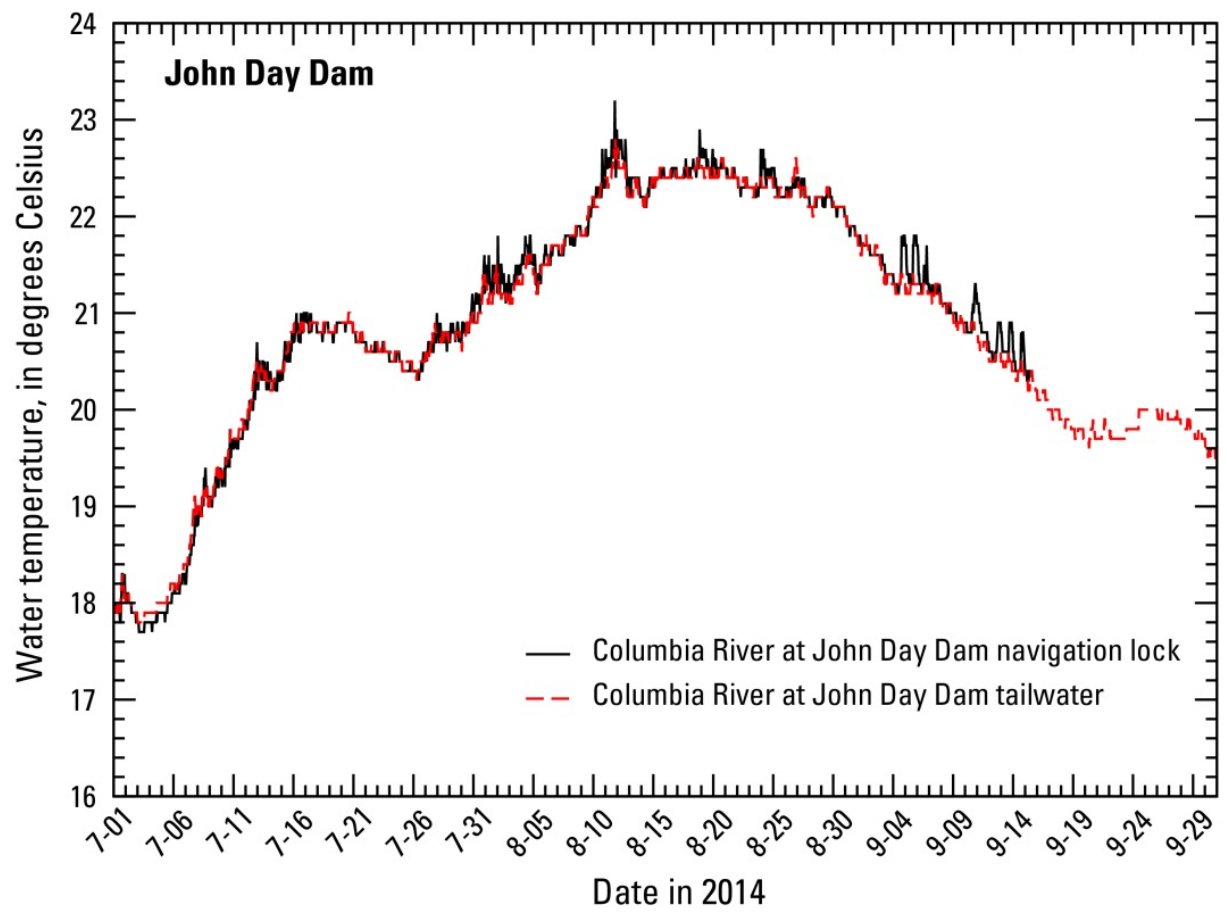

Figure 18. Graph showing hourly water temperature values upstream of John Day Dam and downstream of John Day Dam, lower Columbia River, Oregon and Washington, summer 2014.

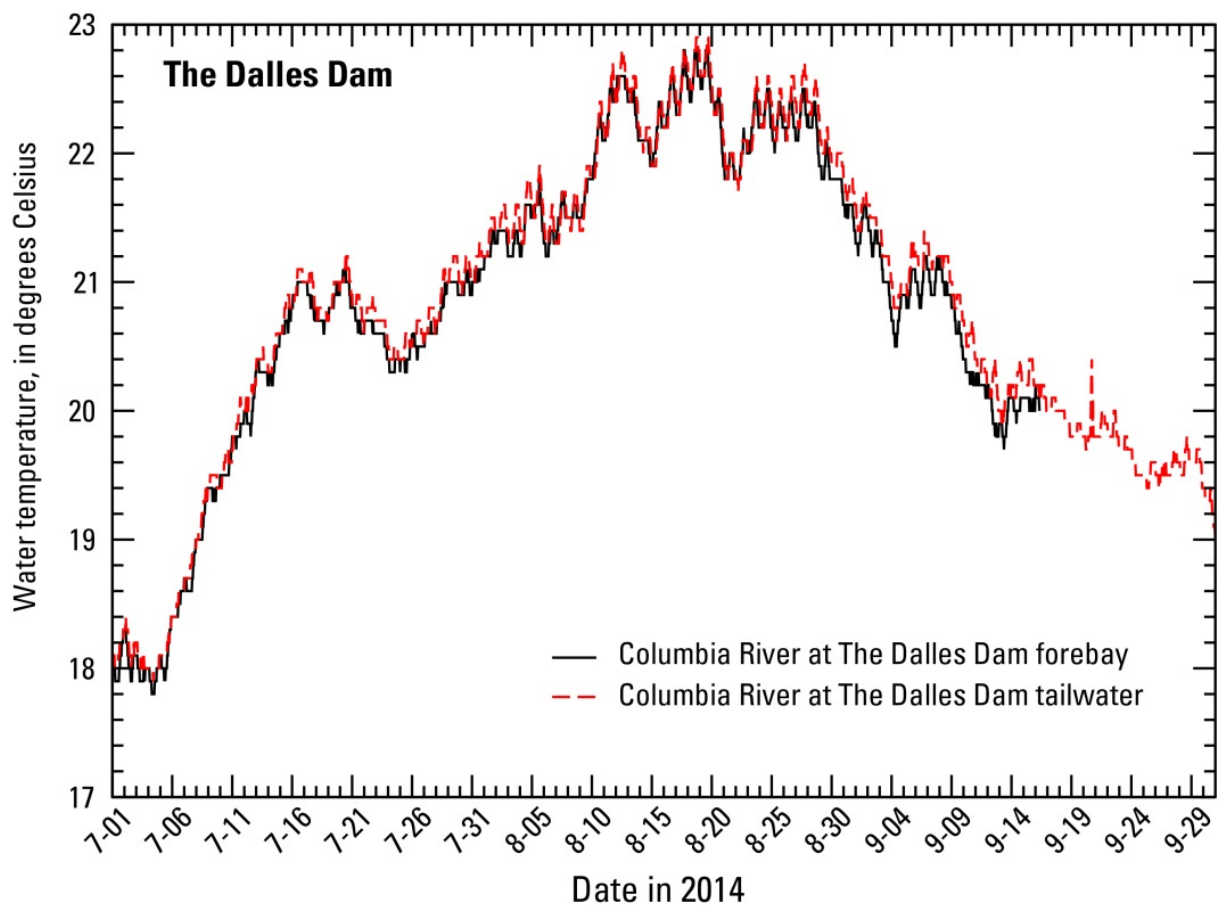

Figure 19. Graph showing hourly water temperature values upstream and downstream of The Dalles Dam, lower Columbia River, Oregon and Washington, summer 2014. 


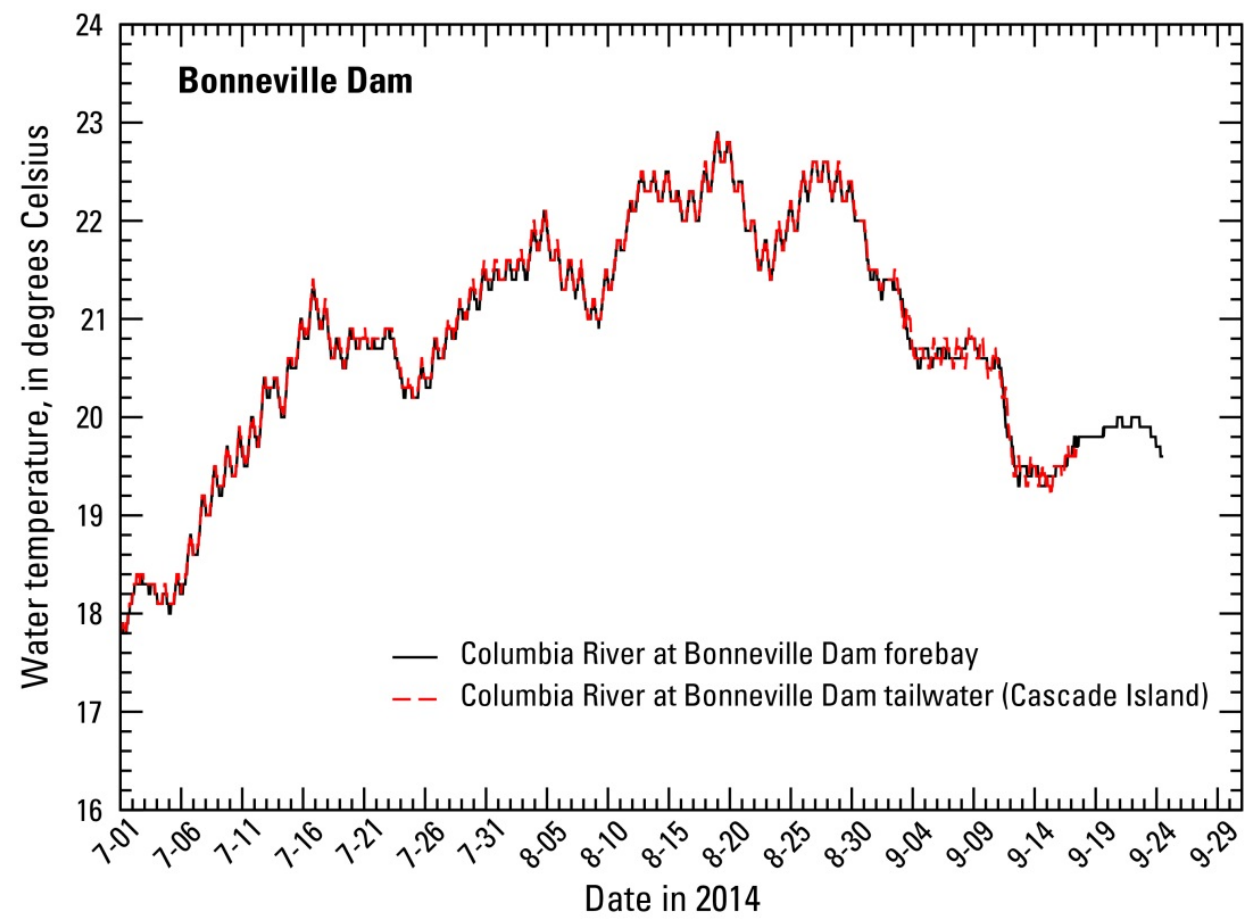

Figure 20. Graph showing hourly water temperature values upstream of Bonneville Dam and downstream of Bonneville Dam at Cascade Island, lower Columbia River, Oregon and Washington, summer 2014.

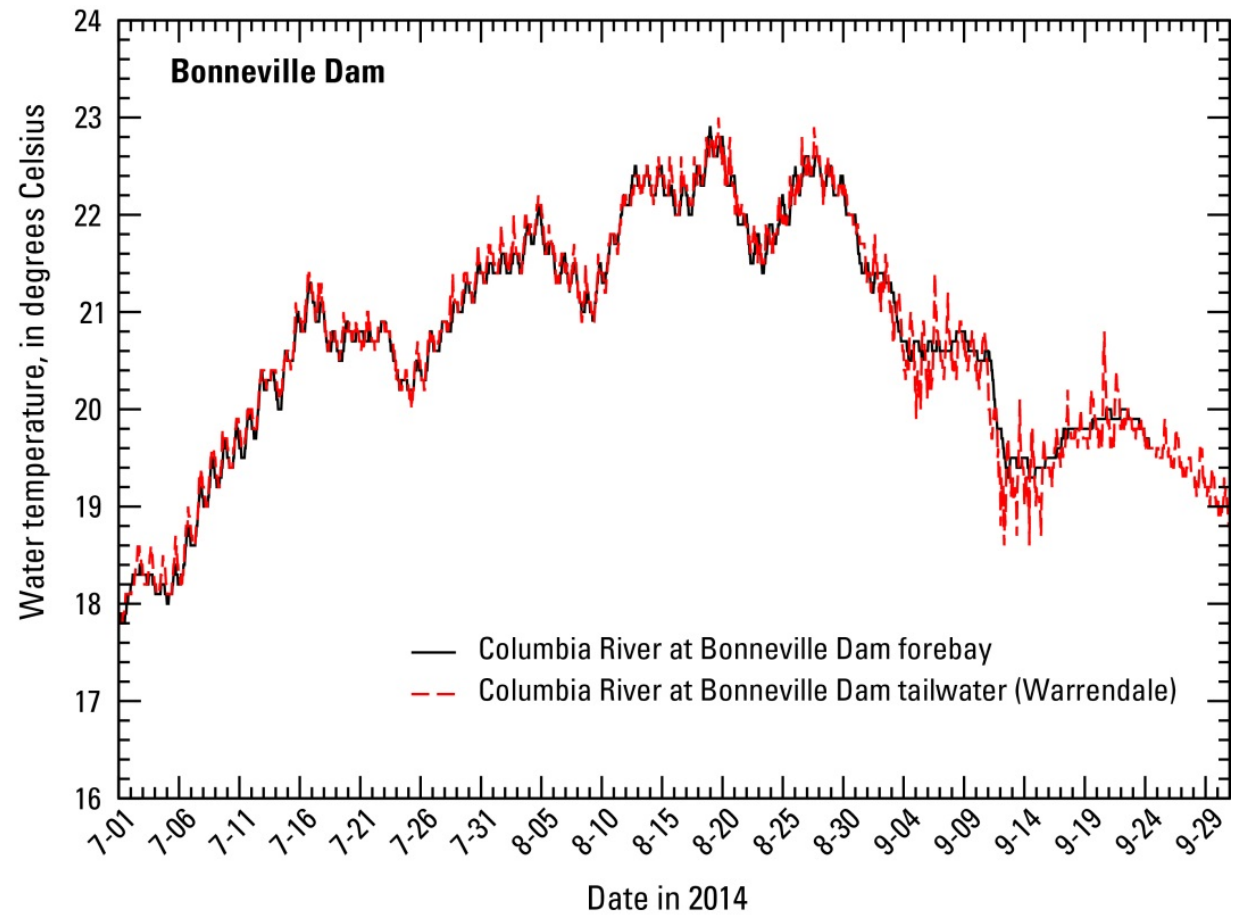

Figure 21. Graph showing hourly water temperature values upstream of Bonneville Dam and downstream of Bonneville Dam at Warrendale, lower Columbia River, Oregon and Washington, summer 2014. 


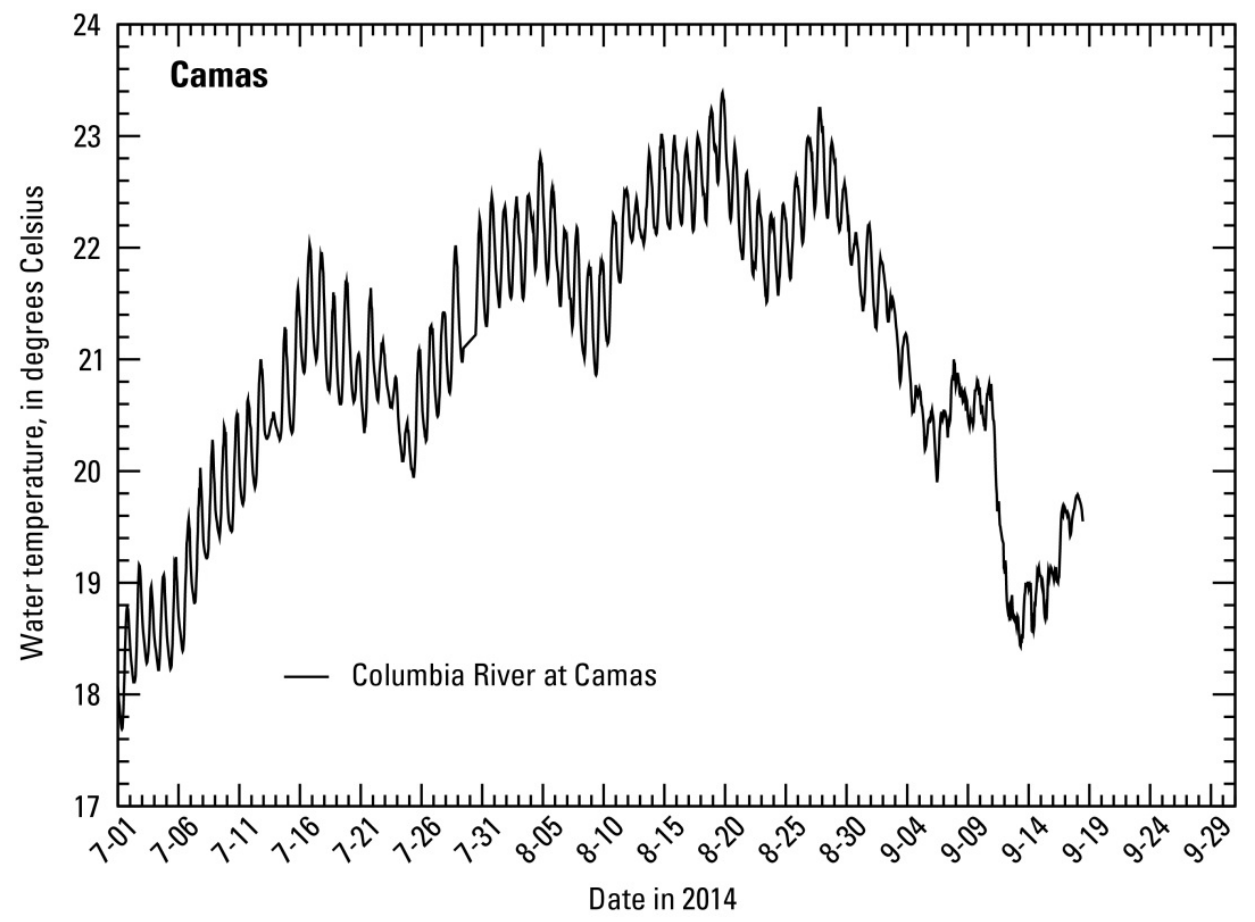

Figure 22. Graph showing hourly water temperature values downstream of Bonneville Dam at Camas, lower Columbia River, Oregon and Washington, summer 2014.

\section{Acknowledgments}

The authors extend special thanks to Tina Lundell (U.S. Army Corps of Engineers) for technical and logistical support of the project. The authors also thank Amy M. Brooks (U.S. Geological Survey [USGS]) for reviewing the data and Danial Polette (USGS) for conducting field and laboratory calibration checks.

\section{References Cited}

Bragg, H.M., and Johnston, M.W., 2014, Total dissolved gas and water temperature in the lower Columbia River, Oregon and Washington, water year 2013-Quality-assurance data and comparison to waterquality standards: U.S. Geological Survey Open-File Report 2013-1281, 27 p., http://dx.doi.org/10.3133/ofr20131281.

Colt, J., 1984, Computation of dissolved gas concentrations in water as functions of temperature, salinity, and pressure: American Fisheries Society Special Publication 14, 154 p.

Jones, J.C., Tracey, D.C., and Sorensen, F.W., eds., 1991, Operating manual for the U.S. Geological Survey's data-collection system with the Geostationary Operational Environmental Satellite: U.S. Geological Survey Open-File Report 91-99, 237 p., http://pubs.er.usgs.gov/usgspubs/ofr/ofr9199.

Tanner, D.Q., and Bragg, H.M., 2001, Quality-assurance data, comparison to water-quality standards, and site considerations for total dissolved gas and water temperature, lower Columbia River, Oregon and Washington, 2001: U.S. Geological Survey Water-Resources Investigations Report 2001-4273, 14 p., http://pubs.er.usgs.gov/usgspubs/wri/wri014273. 
Tanner, D.Q., Bragg, H.M., and Johnston, M.W., 2003, Total dissolved gas and water temperature in the Lower Columbia River, Oregon and Washington, 2003-Quality-assurance data and comparison to water-quality standards: U.S. Geological Survey Water-Resources Investigations Report 2003-4306, 24 p., http://pubs.er.usgs.gov/usgspubs/wri/wri034306.

Tanner, D.Q., Bragg, H.M., and Johnston, M.W., 2004, Total dissolved gas and water temperature in the Lower Columbia River, Oregon and Washington, 2004-Quality-assurance data and comparison to water-quality standards: U.S. Geological Survey Scientific Investigations Report 2004-5249, 27 p., http://pubs.er.usgs.gov/usgspubs/sir/sir20045249.

Tanner, D.Q., Bragg, H.M., and Johnston, M.W., 2005, Total dissolved gas and water temperature in the Lower Columbia River, Oregon and Washington, 2005-Quality-assurance data and comparison to water-quality standards: U.S. Geological Survey Data Series 148, 31 p., http://pubs.er.usgs.gov/usgspubs/ds/ds148.

Tanner, D.Q., Bragg, H.M., and Johnston, M.W., 2006, Total dissolved gas and water temperature in the Lower Columbia River, Oregon and Washington, 2006-Quality-assurance data and comparison to water-quality standards: U.S. Geological Survey Data Series 235, 24 p., http://pubs.er.usgs.gov/usgspubs/ds/ds235.

Tanner, D.Q., Bragg, H.M., and Johnston, M.W., 2007, Total dissolved gas and water temperature in the Lower Columbia River, Oregon and Washington, 2007-Quality-assurance data and comparison to water-quality standards: U.S. Geological Survey Open-File Report 2007-1408, 23 p., http://pubs.er.usgs.gov/usgspubs/ofr/ofr20071408.

Tanner, D.Q., Bragg, H.M., and Johnston, M.W., 2008, Total dissolved gas and water temperature in the Lower Columbia River, Oregon and Washington, 2008-Quality-assurance data and comparison to water-quality standards: U.S. Geological Survey Open-File Report 2008-1357, 25 p., http://pubs.er.usgs.gov/usgspubs/ofr/ofr20081357.

Tanner, D.Q., Bragg, H.M., and Johnston, M.W., 2009, Total dissolved gas and water temperature in the Lower Columbia River, Oregon and Washington, 2009-Quality-assurance data and comparison to water-quality standards: U.S. Geological Survey Open-File Report 2009-1288, 26 p., http://pubs.usgs.gov/of/2009/1288.

Tanner, D.Q., Bragg, H.M., and Johnston, M.W., 2011, Total dissolved gas and water temperature in the Lower Columbia River, Oregon and Washington, 2010-Quality-assurance data and comparison to water-quality standards: U.S. Geological Survey Open-File Report 2011-1293, 28 p., http://pubs.usgs.gov/of/2010/1293.

Tanner, D.Q., Bragg, H.M., and Johnston, M.W., 2012, Total dissolved gas and water temperature in the lower Columbia River, Oregon and Washington, water year 2011: Quality-assurance data and comparison to water-quality standards: U.S. Geological Survey Open-File Report 2011-1300, 28 p., http://pubs.usgs.gov/of/2011/1300.

Tanner, D.Q., Bragg, H.M., and Johnston, M.W., 2013, Total dissolved gas and water temperature in the lower Columbia River, Oregon and Washington, water year 2012-Quality-assurance data and comparison to water-quality standards: U.S. Geological Survey Open-File Report 2012-1256, 26 p., http://pubs.usgs.gov/of/2012/1256.

Tanner, D.Q., Harrison, H.E., and McKenzie, S.W., 1996, Total dissolved gas, barometric pressure, and water temperature data, lower Columbia River, Oregon and Washington, 1996: U.S. Geological Survey Open-File Report 96-662A, 85 p., http://pubs.er.usgs.gov/usgspubs/ofr/ofr96662A. 
Tanner, D.Q. and Johnston, M.W., 2001, Data-collection methods, quality-assurance data, and site considerations for total dissolved gas monitoring, lower Columbia River, Oregon and Washington, 2000: U.S. Geological Survey Water-Resources Investigations Report 2001-4005, 19 p., http://pubs.er.usgs.gov/usgspubs/wri/wri014005.

Tanner, D.Q., Johnston, M.W., and Bragg, H.M., 2002, Total dissolved gas and water temperature in the Lower Columbia River, Oregon and Washington, 2002-Quality-assurance data and comparison to water-quality standards: U.S. Geological Survey Water-Resources Investigations Report 2002-4283, 12 p., http://pubs.er.usgs.gov/usgspubs/wri/wri024283.

U.S. Army Corps of Engineers, 2008, Plan of action for dissolved gas monitoring in 2010-2014: Portland, Oregon, 17 p.

U.S. Army Corps of Engineers, 2014, Total Dissolved Gas Reports: U.S. Army Corps of Engineers, Northwest Division, Columbia Basin Water Management Web site, accessed October 27, 2014, at http://www.nwd-wc.usace.army.mil/ftppub/water_quality/.

U.S. Environmental Protection Agency, 1986, Quality criteria for water 1986: U.S. Environmental Protection Agency Publication No. 440-5-86-001, http://water.epa.gov/scitech/swguidance/standards/criteria/aqlife/upload/2009_01_13_criteria_goldboo k.pdf. 


\section{$\frac{1}{2}$}

$\stackrel{\square}{\mathbb{\Xi}}$

产

0
운
0
0
0
0
0

ISSN 2331-1258 (online)

http://dx.doi.org/10.3133/ofr20141237 